\title{
Environmentally sustainable mining: a case study of intermittent cut-and-fill mining under sand aquifers
}

\author{
Jiawei Liu ${ }^{1} \cdot$ Wanghua Sui $^{1}$ (I) $\cdot{\text { Qingjie } \text { Zhao }^{2}}^{2}$
}

Received: 29 August 2016/Accepted: 7 August 2017/Published online: 17 August 2017

(c) The Author(s) 2017. This article is an open access publication

\begin{abstract}
This paper presents an investigation on the effects of intermittent cut-and-fill mining on the overburden failure under sand aquifers. In the intermittent cut-andfilling method, the panel is divided into long pillars, and then entries in every long pillar into a narrow strip; every narrow strip is then cut and backfilled. Field measurements, scale model tests and numerical simulations are used to compare overburden failure and subsidence due to three mining methods: intermittent cut-and-fill mining, longwall excavation and continuous filling. These methods were applied in a case study of the Taiping Coal Mine, in Shandong, China. The results of the numerical simulation and scale model testing reveal that the height of the maximum caving and water-conducting fractured zones, and the maximum subsidence due to intermittent cut-and-fill mining are much smaller than those with the use of longwall excavation and continuous filling and well verified by the field measurements. Additionally, the numerical simulation results of the stress distribution and variation during intermittent cut-and-fill mining are in close agreement with those of the field measurements. It has been proved that the intermittent cut-and-fill mining can successfully mitigate
\end{abstract}

Wanghua Sui

suiwanghua@cumt.edu.cn

Jiawei Liu

ljwcumt@126.com

Qingjie Zhao

qjiezhao@126.com

1 School of Resources and Geosciences, State Key Laboratory for Geomechanics and Deep Underground Engineering, China University of Mining and Technology, 1 University Rd, Xuzhou 221116, Jiangsu, China

2 The Taiping Coal Mine, Jining 272000, Shandong, China the overburden failure and subsidence, which contribute to preventing water and sand inrush into coal mines under sand aquifers. This provides a less costly and more effective approach to address surface subsidence and mine caving problems.

Keywords Sand aquifers · Intermittent cut-and-fill mining · Overburden failure $\cdot$ Fractured zone $\cdot$ Caving zone $\cdot$ Subsidence

\section{Introduction}

Water and sand inrush may occur when the fractured zone induced by coal mining penetrates the sand aquifers that overlie the coal seams and contain sand and gravel layers. There has been many researches on the mechanism of overburden failure and strata deformation induced by coal mining under sand aquifers (Sui et al. 2015a, b). The mining methods that mitigate overburden failure and subsidence and prevent water inrush due to coal mining have been widely studied, such as slice, room-and-pillar, backfill and strip mining (Iwanec et al. 2016; Ghasemi et al. 2012; An et al. 2016; Gao and Ge 2016). Among these mining options, strip and backfill mining are considered to be the most effective methods to mitigate overburden failure and prevent coal mine from groundwater disasters.

When mining activities are conducted under buildings, railways and water bodies, different types of problems are need to be addressed: the problems of surface subsidence which would cause deformation and destruction of buildings and railways and the problems of overburden failure which would lead to water and/or sand inrush as the fractured zone penetrates the aquifers (Djamaluddin et al. 2011). As a partial mining method, strip mining is mainly 
used when mining is carried out under buildings, railways and water bodies with less cost and often used due to its practicality. Since coal seams are divided into several strips, the remaining coal pillars should provide temporary or permanent support to maintain and support the overburden strata. However, a low recovery ratio has a negative effect on the production of coal mines, as well as the roomand-pillar mining which is a method of working preferable for flat, tabular and thin seams, where the pillars formed by rooms or entries produced in the solid coal in the development panels (Ghasemi and Shahriar 2012; Ghasemi et al. 2014). Additionally, the conventional coal pillar can be replaced by a backfilled room-and-pillar in underground coal mining in order to confine and support the rock mass, thereby limiting the amount of convergence (Tesarik et al. 2009). In recent years, backfill mining has become a popular and widely used mining method with a high recovery ratio and can effectively control roof and overlying strata movement (Zhang et al. 2016). Furthermore, the backfill mining can greatly decrease the abutment stress compared to the longwall excavation mining (Deng et al. 2016).

Backfill mining approach originated in Australia, where dry, water and cement filling were carried out. Paste backfill mining, which uses cement fill, was first applied in the Bad Grund mine in the 1970s to mine lead, zinc and ore, and the technology has then become widely used in coal mines since the 1990s (Rankine and Sivakugan 2007). Filling mining in China has been implemented for over 40 years. The first coal mine that used paste backfill mining was the Taiping Coal Mine in 2006, in which the coal seams under thick unconsolidated aquifers and thin bedrocks were successfully exploited, and there was improvement in reducing surface subsidence damage from roof control. Moreover, there have been significant economic, environmental and safety benefits to the Taiping Coal Mine since then, and backfill mining is shown to be a good solution to the major problem of coal mining under buildings without relocating the villages. The paste backfill material used in backfill mining is often composed of fly ash, sand and cement material, etc. (Fall et al. 2008). Paste backfill material is a core component of paste backfill technology, and many researches have been carried out on the properties, such as early and long-term strengths, resistance to compression, flow and creep (Fall et al. 2007). The results have shown that paste backfill material has a high early strength and strain hardening takes place at low confining pressures with $0.5-1 \mathrm{MPa}$ (Yilmaz et al. 2014). Many researchers have demonstrated that backfill can ensure stability of the surrounding rocks and coal pillars during mining, even improving long-term underground safety by supporting the coal roof and maintaining the strength of the support pillars (Tesarik et al. 2009). The backfill becomes part of surrounding rocks and integrates with them, and the coal pillar strength is increased due to the lateral restraint of the backfill, so then the post-failure stress is greater for the constrained pillars than the postfailure stress in the unconstrained pillars (Tesarik et al. 2003; Kostecki and Spearing 2015). Previous research has shown that paste backfilling has a much higher recovery rate and can effectively control the movement and deformation induced by overburden pressure and surface subsidence compared to other mining methods, such as strip mining and longwall excavation (Belem and Benzaazoua 2008; Fall et al. 2009; Xu et al. 2011; Yao et al. 2012; Zhang et al. 2012). However, in order to maximize the coal pillar recovery rate with stripping, some new mining methods have surfaced that combine strip and backfill mining, such as backfill strip mining underground, backfill grouting in zones of caving rock and bed separation with strip mining and continuous filling.

Coal mining under sand aquifers can be complex. The thin bedrock cannot support a stable structure such as masonry beams during strip mining, and the deformation due to the wavy stratum extends to the upper layers. Moreover, overburden failure after mining cannot be controlled in a timely manner with continuous filling, which may lead to a negative effect on controlling surface subsidence. Thus, an intermittent cut-and-fill mining method has been adopted in different coal mines. The intermittent filling time is a unique factor that provides time for the backfill to consolidate in maintaining stability. First, the panel is divided into long pillars, and then entries in every long pillar into a narrow strip. Cyclical mining is advanced around narrow coal pillars with a certain distance, and then filling is carried out during the excavation of the narrow coal pillars in the next wide strip. Mining and filling are carried out at the same time, but separated with a certain distance, and thus the new backfill will have enough time to consolidate in maintaining stability. The continuous filling method here means a simultaneous mining and filling with no interval until the end of the production in a panel. This paper will investigate the stress distribution, subsidence and overburden failure due to intermittent cutand-fill mining to explain its environmental sustainability. The numerical simulations and scale model testing mainly focus on the evolution of the stress toward the coal pillars and backfill, and the prediction of the height of the overburden failure and subsidence due to longwall mining, continuous filling and intermittent cut-and-fill mining activities, based on a case study of Seam No. 3 of the Permian Shanxi Formation in the Taiping Coal Mine, located in Shandong, China. 


\section{Geological setting and hydrogeological engineering conditions}

\section{The Taiping Coal Mine}

The Taiping Coal Mine is located in the county of Zoucheng, $188 \mathrm{~km}$ southwest of Jinan, which is the capital of the Shandong province in China (Fig. 1). The Taiping Coal Mine encompasses an area of approximately $22 \mathrm{~km}^{2}$, with a length of $7.1 \mathrm{~km}$ in the north-to-south direction and a width of $3.1 \mathrm{~km}$ in the east-to-west direction. The No. 3 coal seam in the Permian Shanxi Formation is a productive coal seam with an average thickness of $8.85 \mathrm{~m}$ under sand aquifers and surrounded by thin bedrock formations. Furthermore, more than 2 million tons of coal has been mined out by using paste backfilling from 9 other panels since 2006.

\section{Geology and hydrogeology}

Geologically, the Taiping Coal Mine is located in the southwestern part of the Yanzhou coalfield which is located on the eastern rim of the depression zone in the Western Shandong Block of the North China Platform. A schematic of the planar graph of the Taiping Coal Mine which depicts the distribution of the panels is shown in Fig. 2. Figure 3 is an illustration of the geological cross section of Panel S01, which is examined for overburden failure. The No. 3 coal seam has a thickness that varies from 2.10 to $9.97 \mathrm{~m}$ and a dip angle of $5^{\circ}-15^{\circ}$. The lithology of the overburden strata mainly consists of mudstone, fine sandstone and siltstone. The geological structure of the mine is consistent with the regional structural features. The gentle secondary fold is the main structure with an axial direction of northeast with a small number of faults in this area. The strike directions of the normal faults are nearly north-south, while the reverse faults are oriented east-west, and the throw of these faults varies from 0.5 to $9 \mathrm{~m}$.

The hydrogeological structure, which affects the mining of the No. 3 coal seam, consists of sandstone aquifers in the bedrock of the Permian age, clay aquitard and sand aquifer in the unconsolidated Neogene layers. The bedrock aquifers are dewatered during the mining process, so they have little impact on mining safety. However, the bottom aquifer of the Neogene system has a specific capacity of $0.023-0.11 \mathrm{~L} /(\mathrm{s} \mathrm{m})$, which is classified as weak to medium in water abundance in accordance with the regulations of preventing water hazards for coal mines (China State Administrator of Coal Mine Safety 2009), and safety pillars should be established to prevent water hazards. Fortunately, the Neogene bottom clay layer that has a thickness from 0 to $14.2 \mathrm{~m}$ can be considered as the protective layer which would prevent water inrush.

\section{Engineering geology}

The overburden bedrock with a thickness that ranges from 0 to $32.6 \mathrm{~m}$ is thin compared to the unconsolidated Neogene layers with an average thickness of $158.95 \mathrm{~m}$. The geotechnical properties of the geological sections in the Permian Shanxi Formation are listed in Table 1. The overburden bedrock is mainly mudstone and fine sandstone, and the mudstone can be easily damaged due to mining by longwall excavation. The overburden strength ranges from low to medium, which is beneficial for mining safety because the height of the water-conducting fractured zone is reduced. However, the unconsolidated Neogene layers deposited on the overburden bedrock consist of clayey, coarse and alternating sands, as well as gravel. The height of the water-conducting fractured zone should be carefully controlled during coal mining to avoid water and sand inrush from the unconsolidated layers.

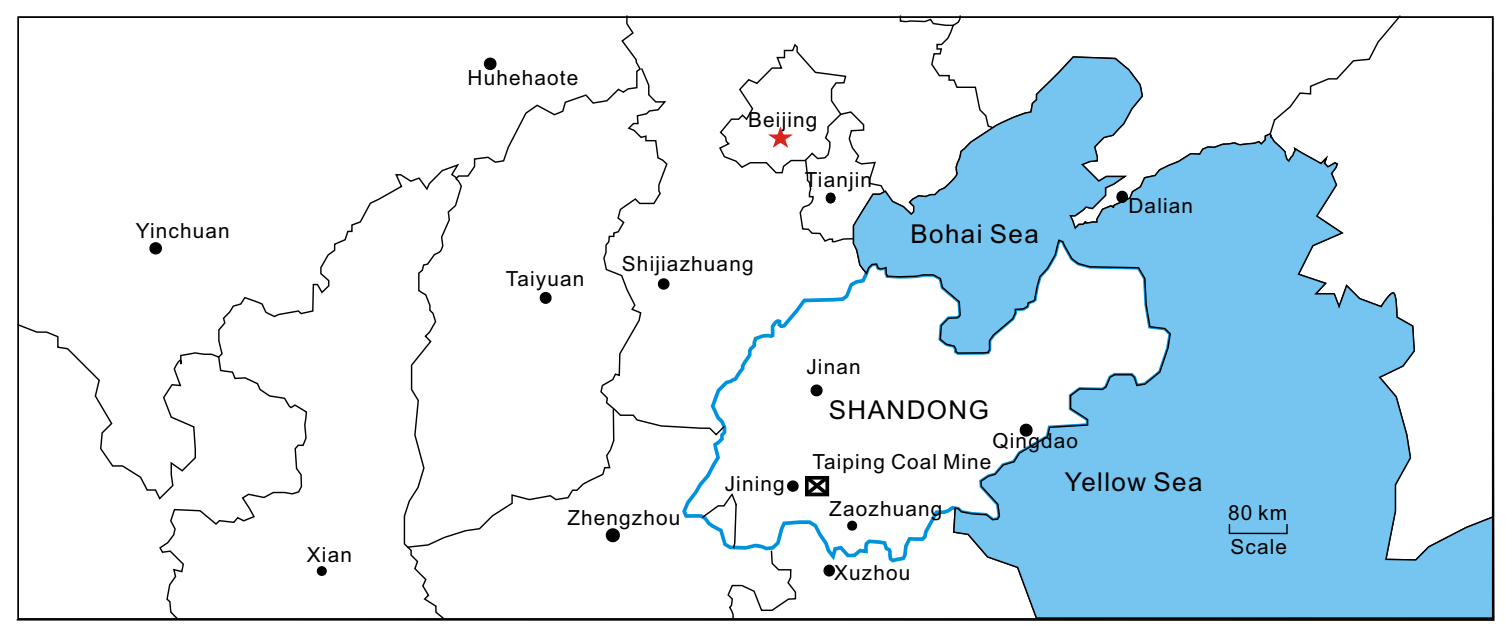

Fig. 1 Location of the Taiping Coal Mine 


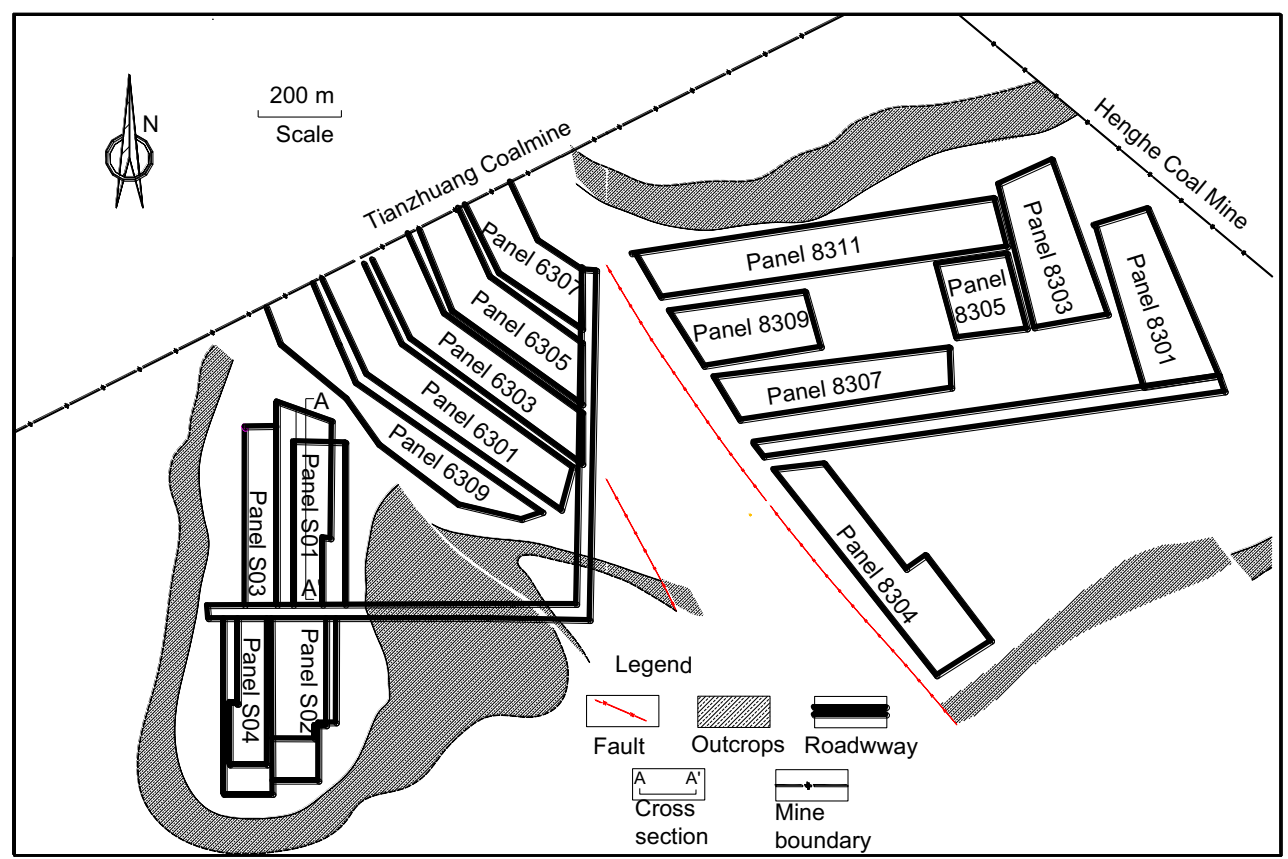

Fig. 2 Layout of panels in the Taiping Coal Mine

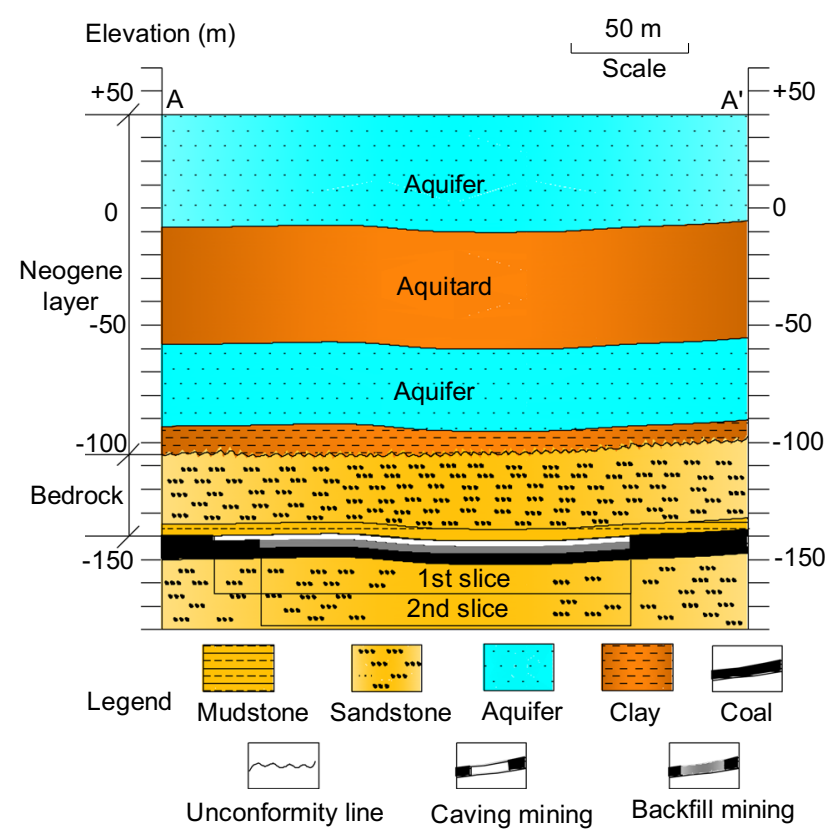

Fig. $3 A-A^{\prime}$ cross section along the strike of Panel SO1

\section{Methodology}

\section{Mining method and the properties of paste backfill materials}

In the intermittent cut-and-fill mining method, the panel is firstly divided into long pillars with a width of $27.2 \mathrm{~m}$, while every entry has a width of $3.4 \mathrm{~m}$. Then, 3.4-m entries are cut and filled with paste fill. The second step, 3.4-m- wide entry slices adjacent to the previously paste-filled entries in every long pillar are cut and filled. And this process continues until all the panel is excavated and filled. Figure 4 shows the mining process in which intermittent cut-and-fill mining is used: (1) First, a small coal pillar is extracted in each group with panel advance; the mined out area is backfilled while extracting a narrow coal pillar in the next group; and finally, all the small mined areas are replaced with paste backfill material in each group. There is a certain distance between every two backfills; (2) when the first cycle is completed, the same mining sequence is carried out and the same specification applies for the backfill next to the backfill in the last cycle in the advancing direction; and (3) the remaining strips in the panel are all mined out and backfilled.

The paste backfill materials used in the Taiping Coal Mine consist of fly ash, sand from the Sihe River, water and shrinkage-limited (SL) cement. The materials have an affinity for mud, strong consolidation capability, high early strength and continuous growth in strength in the late ages so that the stability of the backfill can be ensured. Moreover, the materials are low in cost and readily available.

Table 2 shows the paste backfill material mixture ratio, and Table 3 shows the uniaxial compressive strength (UCS) and cohesion of the paste backfill material. The UCS of the paste backfill material increases with curing age (Fig. 5). The paste material was pumped into the filling bag in the panel through the pumping system, and then, the paste backfill material was placed into a narrow confined opening. The surrounding rock mass and backfill interact in a complex manner ( $\mathrm{Li}$ and Aubertin 2008; Li et al. 2011). 
Table 1 Geological and mechanical properties of coal measures

\begin{tabular}{|c|c|c|c|c|c|c|c|c|c|}
\hline Stratigraphy & Lithology & $\begin{array}{l}\text { Thickness } \\
(\mathrm{m})\end{array}$ & $\begin{array}{l}\text { Unit } \\
\text { weight } \\
\left(\mathrm{kN} / \mathrm{m}^{3}\right)\end{array}$ & $\begin{array}{l}\text { Compressive } \\
\text { strength } \\
(\mathrm{MPa})\end{array}$ & $\begin{array}{l}\text { Tensile } \\
\text { strength } \\
(\mathrm{MPa})\end{array}$ & $\begin{array}{l}\text { Elastic } \\
\text { modulus } \\
(\mathrm{GPa})\end{array}$ & $\begin{array}{l}\text { Poisson's } \\
\text { ratio }\end{array}$ & $\begin{array}{l}\text { Cohesion } \\
(\mathrm{MPa})\end{array}$ & $\begin{array}{l}\text { Angle of } \\
\text { internal } \\
\text { friction }\left(^{\circ}\right)\end{array}$ \\
\hline \multirow[t]{6}{*}{ Neogene } & Clay with sand & 36.2 & 22.0 & - & - & - & - & 0.01 & 13 \\
\hline & Alternate sand and clay & 28.0 & 21.0 & - & - & - & - & 0.03 & 15 \\
\hline & Sandy clay with sand & 17.0 & 21.0 & - & - & - & - & 0.02 & 19 \\
\hline & Clayey sand & 28.5 & 20.0 & - & - & - & - & 0.04 & 18 \\
\hline & Clay and sandy clay & 8.3 & 19.5 & 4.8 & - & 0.056 & 0.29 & 0.05 & 20 \\
\hline & $\begin{array}{l}\text { Sand, clayey sand } \\
\text { and clay }\end{array}$ & 36.5 & 21.0 & 3.2 & 0.006 & 0.22 & 0.32 & 0.12 & 32 \\
\hline \multirow{4}{*}{$\begin{array}{l}\text { Permian Shanxi } \\
\text { formation }\end{array}$} & Sandstone & 26.0 & 26.0 & 24.0 & 1.50 & 2.20 & 0.24 & 6.9 & 37 \\
\hline & Mudstone & 3.0 & 25.0 & 5.7 & 0.45 & 0.35 & 0.35 & 4.3 & 33 \\
\hline & Coal & 8.5 & 22.0 & 8.45 & 0.51 & 1.15 & 0.29 & 2.6 & 32 \\
\hline & Sandstone & 15.5 & 27.0 & 21.0 & 1.55 & 1.55 & 0.3 & 7.5 & 38 \\
\hline
\end{tabular}

- Not applicable

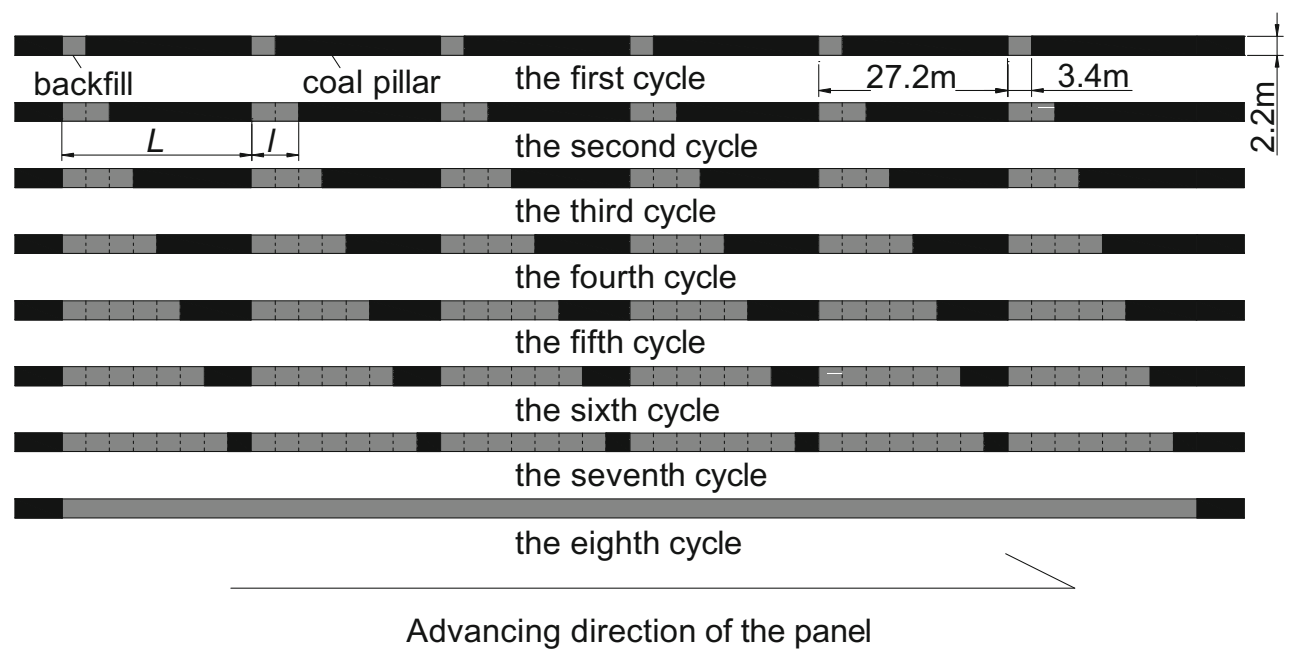

Fig. 4 Flowchart of intermittent cut-and-fill mining. $L$ wide strip; $l$ narrow strip

Table 2 Mixture ratio of paste backfill material

\begin{tabular}{lllll}
\hline Raw material & $\begin{array}{l}\text { Dry } \\
\text { sand }\end{array}$ & $\begin{array}{l}\text { Fly } \\
\text { ash }\end{array}$ & $\begin{array}{l}\text { Cementing } \\
\text { material }\end{array}$ & Water \\
\hline Mass proportion $(\%)$ & 64.31 & 4.82 & 7.10 & 23.77 \\
\hline
\end{tabular}

The surrounding rock mass then holds the backfill by shear forces along the interfaces, forming a three-dimensional stress state in the backfill, and a strain hardening process takes place at a low confined pressure. Thus, the paste backfill can support the overburden so that the formation movement induced by mining would not reach the ground surface and the water-conducting fractured zone will not penetrate the upper aquifers, which would address the mining safety requirements for sand aquifers in the Taiping Coal Mine.

\section{Field measurements}

Field measurements have been one of the most effective and direct methods to investigate the stress distribution in the rock, the height of overburden failure zones and subsidence after mining. Figure 6 shows the layout of field measurement points for the Panels 8311 and S01. The field measurement for the height of overburden failure was conducted in the Panel 8311, while for the stress distribution and the subsidence in the Panel S01. Both panels adopted the paste backfill mining.

Generally, the stress distribution in the roof can be characterized by the load on the single hydraulic support during the mining process. The YHY-60 hydraulic dynamometer was used to measure the cyclical support pressure before shifting the support in the Panel S01. 
Table 3 Mechanical parameters of paste backfill material

\begin{tabular}{llcccc}
\hline Curing age $(\mathrm{d})$ & 1 & 3 & 7 & 14 & 28 \\
\hline Average value of UCS (MPa) & 0.14 & 0.29 & 0.57 & 0.75 & 1.12 \\
Poisson's ratio & - & 0.47 & 0.41 & 0.37 & 0.34 \\
Cohesion $(\mathrm{kPa})$ & 74.8 & 213.7 & 379.2 & 544.8 & 649.7 \\
Angle of internal friction $\left(^{\circ}\right)$ & 17.5 & 15.8 & 15.2 & 14.5 & 14.3 \\
\hline
\end{tabular}

- Not applicable

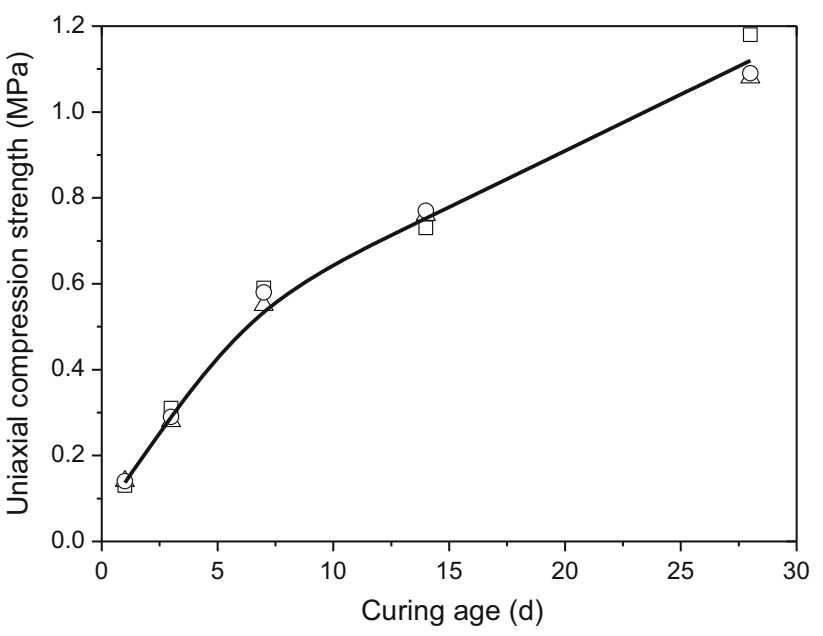

Fig. 5 UCS of paste backfill materials with curing age

Furthermore, the subsidence observation station was set up in the Panel S01 to measure subsidence.

The boreholes were carried out before and after mining in the Panel 8311, and then the water loss was measured by the two-terminal plugging tool in different locations to determine the height of the overburden failure zones.

\section{Scale model testing}

Scale model testing was used to examine overburden failure in the Taiping Coal Mine which is used as a case study in this research work. Two engineering geological models were used for the strike and dip directions of the Panel S01. The coal seam was divided into two slices by longwall excavation with a mining thickness of $1.8 \mathrm{~m}$ in the first slice, and continuous filling and intermittent cut-and-fill mining with a mining thickness of $2.2 \mathrm{~m}$ in the second slice, respectively. Figure 7 shows the scale model of the studied area and parameters for the scale model. The elevation of the coal seam with a thickness of $8.4 \mathrm{~m}$ varies from $-150 \mathrm{~m}$ to $-140 \mathrm{~m}$, and the size of the model is $300 \mathrm{~cm} \times 30 \mathrm{~cm} \times 68 \mathrm{~cm} \quad$ (length $\times$ width $\times$ height). Table 4 lists the parameter scales of the model in accordance with the similarity theory (Franz 2008). Materials used for modeling include sand, mica, gypsum, calcium carbonate, water, etc. A distribution load of $14.58 \mathrm{kN}$ was applied on the top of the scale model to simulate the gravitational pressure of the soil layers, which was calculated by the formula as follows:

$q_{\mathrm{m}}=\frac{\gamma\left(H-H_{\mathrm{m}}\right)}{C_{\gamma} C_{l}} \cdot l \cdot b$,

where $q_{\mathrm{m}}$ is the applied distribution load; $H$ is the buried depth of the coal seam; $H_{\mathrm{m}}$ is the height of the overlying strata in the scale model; $\gamma$ is the average unit weight of the overlying strata; $l$ is the length of the model; $b$ is the width of the scale model; $C \gamma$ and $C_{l}$ are the similarity ratios for unit weight and geometry of the model.

The height of overburden failure may not exceed $25 \mathrm{~m}$ according to the previous mining experience in the Taiping Coal Mine. The both boundaries of the model are 40 and $60 \mathrm{~m}$ away from the mined out area, respectively. Therefore, the boundary effects can be mitigated effectively. Moreover, the scale model was free in the vertical direction on both side boundaries and fixed in the bottom and horizontal directions, which provide a lateral restraint. Furthermore, the monitoring points were arranged on the front surface of the model for image acquisition of the overlying strata displacements, while the dial indicators were set on the back surface to collect displacements for calibration.

\section{Numerical simulation}

Fast Lagrangian Analysis of Continua (FLAC 3D code) (Itasca 2009) was used to analyze the evolution of the stress of the coal pillars, backfill and the overburden failure by using the mining sequence in accordance with scale model testing, which showed longwall excavation with a mining thickness of $1.8 \mathrm{~m}$ in the first slice, and continuous filling and intermittent cut-and-fill with a mining thickness of $2.2 \mathrm{~m}$ in the second slice, respectively. The simulated model size was set at $340 \mathrm{~m} \times 340 \mathrm{~m} \times 129 \mathrm{~m}$ (length $\times$ width $\times$ height), in accordance with the engineering geological and mining conditions of the area for intermittent cut-and-fill mining. Figure 8 shows the schematic diagram of the 3D model. There is a boundary with a width of $100 \mathrm{~m}$ in the length and width directions to reduce the boundary effect. Moreover, the both side boundaries and top face are free in vertical displacement and fixed at the bottom and horizontal directions. A vertical pressure of 1.8 $\mathrm{MPa}$ was loaded on the top to simulate the vertical 


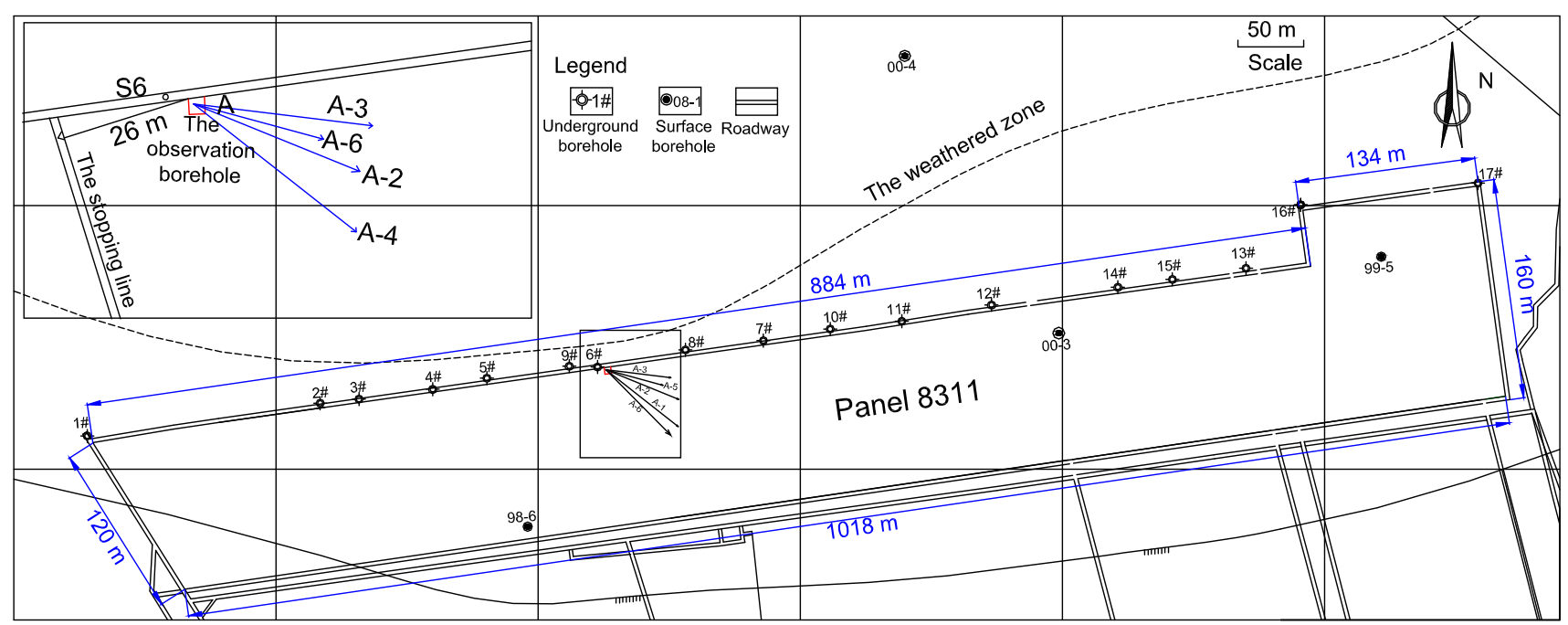

(a)

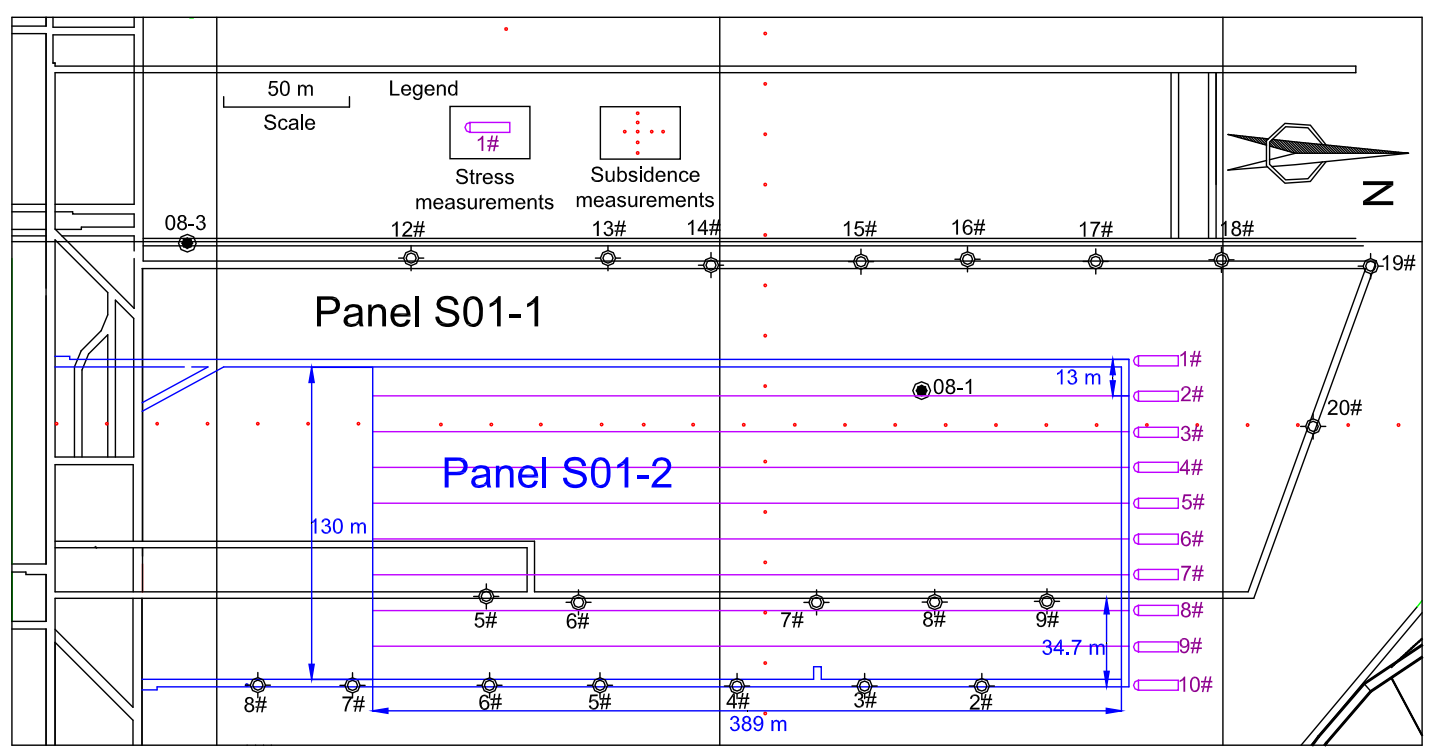

(b)

Fig. 6 Schematic of layout of field measurement points and parameters for Panels S01 and 8311 in the Taiping Coal Mine. a Height of overburden failure measurements for Panel 8311; b subsidence and stress measurements for Panel S01

geostress. The mechanical parameters of overburden are listed in Table 5 and were carefully determined through laboratory testing and geological observations. The properties of rock mass were analyzed with the Mohr-Coulomb criterion, and the coal extraction process was conducted with the null model function.

In this numerical model, when the ratio of the maximum unbalanced force against internal force is less than $10^{-5}$, the maximum unbalanced force may achieve the minimum and imply that the model is convergent. The size of each mesh varied from $3.4 \mathrm{~m} \times 3.4 \mathrm{~m} \times 1.8 \mathrm{~m}$ to $3.4 \mathrm{~m} \times 3.4 \mathrm{~m} \times 6 \mathrm{~m}$ (length $\times$ width $\times$ height $)$; thus, the size of the mesh was small, and the ratios of the side lengths were sufficiently small that there is no deformity in the mesh. However, the calculation efficiency may be lower if the mesh size shrank any further. Therefore, the mesh size in this numerical model may guarantee the precision of the calculation process, which verified the validity of the numerical method.

However, the roof strata collapse with the longwall excavation process, then three zones of disturbance may be identified as a caving zone, fractured zone and continuous deformation zone. The caving rocks will be gradually compacted with the panel advance, and the caving zone and paste backfill materials were analyzed based on double-yield criterion used to simulate the strain hardening process. The 
Fig. 7 Scale model along the strike direction of Panel SOI

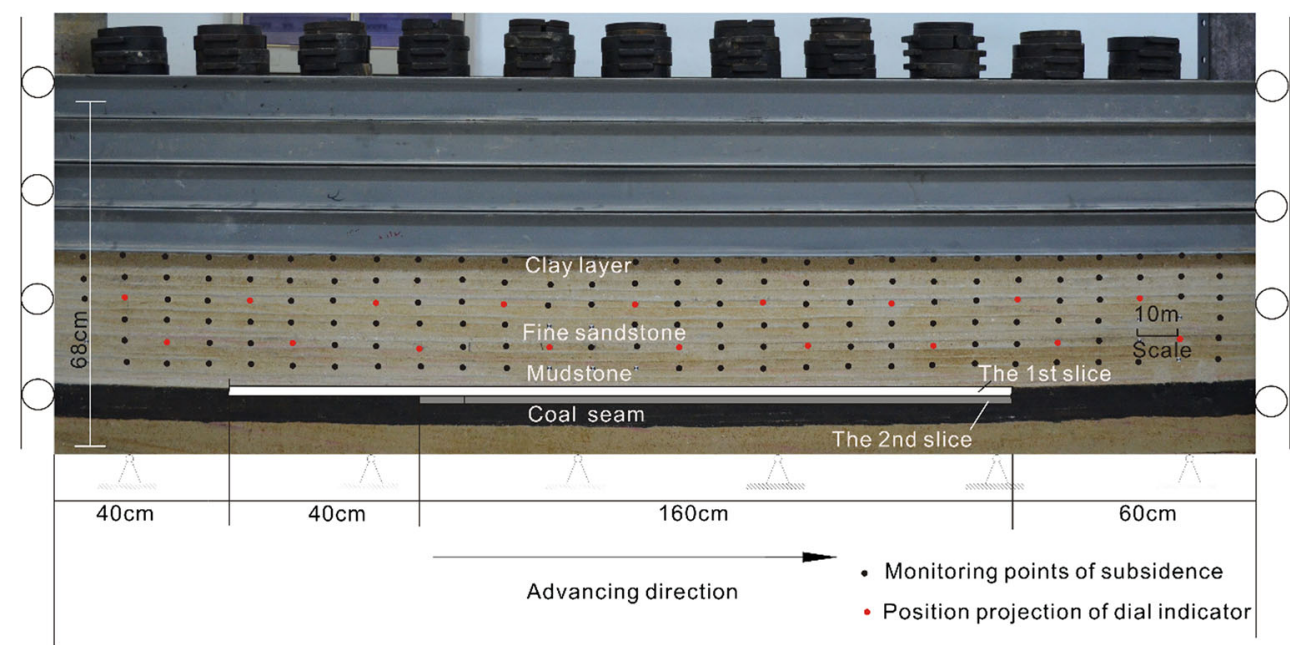

Table 4 Parameter scales of the model

\begin{tabular}{lllllllll}
\hline $\begin{array}{l}\text { Geometry } \\
\text { ratio }\end{array}$ & Size $(\mathrm{m})$ & $\begin{array}{l}\text { Mining thickness } \\
(\mathrm{m})\end{array}$ & Loading method & $\begin{array}{l}\text { Time } \\
\text { ratio }\end{array}$ & $\begin{array}{l}\text { Gravity } \\
\text { ratio }\end{array}$ & $\begin{array}{l}\text { Strength } \\
\text { ratio }\end{array}$ & $\begin{array}{l}\text { Dip angle } \\
\left({ }^{\circ}\right)\end{array}$ & $\begin{array}{l}\text { Direction } \\
1: 100\end{array}$ \\
\hline $3.0 \times 0.3 \times 0.68$ & $1.8 / 2.2$ & $\begin{array}{c}\text { Gravitational pressure } \\
\text { and additional load }\end{array}$ & $1: 10$ & $1: 1.67$ & $1: 166.67$ & 0 & Strike/dip \\
\hline
\end{tabular}

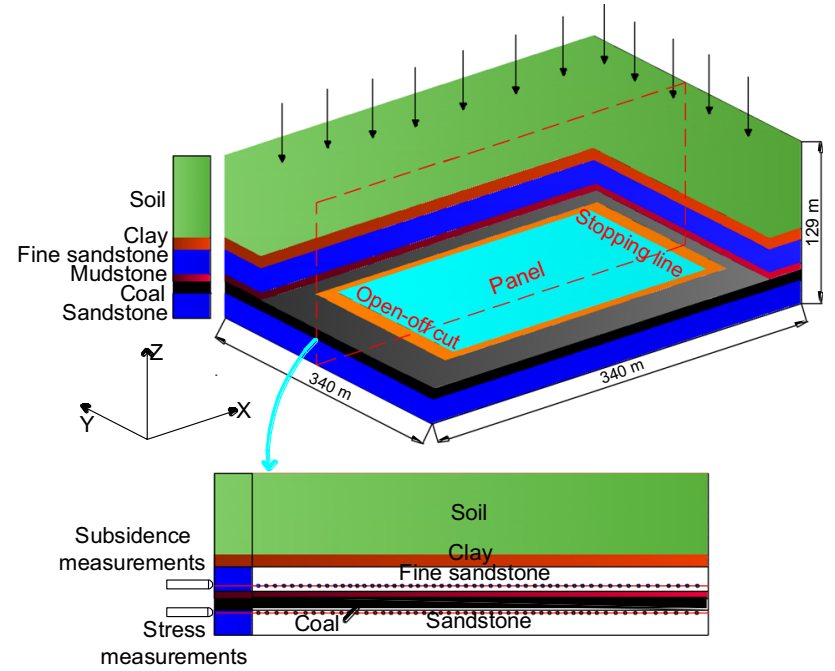

Fig. 8 FLAC 3D schematic model and the layout of monitoring points

simulation parameters for paste backfill and caving zone are calibrated against the results derived from laboratory tests and Salamon model which is widely used in describing the strain hardening behavior, respectively (Ju et al. 2015).

$\sigma=\frac{E_{0} \varepsilon_{v}}{1-\varepsilon_{v} / \varepsilon_{v}^{m}}$

where $\sigma$ is the applied compressive stress to the caving rock; $E_{0}$ is the initial tangential modulus of the caving rock; $\varepsilon_{\mathrm{v}}$ is the volumetric strain; and $\varepsilon_{\mathrm{v}}^{\mathrm{m}}$ is the maximum volumetric strain.
Figure 9 illustrates the fitted results of the input parameters for double-yield material model and the theoretical results derived from Salamon model or laboratory tests. The double-yield material model is a cap pressure table which relates cap pressure to plastic volumetric strain. The figure indicates that the stress-strain relationship chosen in the simulation is also verified. Table 6 shows the simulation parameters for paste backfill and cave-in material. The monitoring lines of stress were placed below the coal seam floor at $1 \mathrm{~m}$, and those of displacement over the coal seam roof at $5 \mathrm{~m}$ to monitor the stress of the coal pillars and the backfill and roof deformation (Fig. 8). There were a total of 101 monitoring points in each monitoring line with a distance of $3 \mathrm{~m}$.

In addition, only the gravity stress was considered in the initial equilibrium process and a distribution load was applied on the top of the model to compensate the vertical gravity of the soil layers.

\section{Results and analysis}

\section{Stress evolution and verification by the field measurements}

Figure 4 shows the flowchart of the mining process by using intermittent cut-and-fill mining in the Taiping Coal Mine, which is the case study used in this research work. There are 6 wide strips, each with a width of $27.2 \mathrm{~m}$, and 
Table 5 Geological strata and mechanical properties of coal measures

\begin{tabular}{lcllllllll}
\hline Geological strata & $\begin{array}{l}\text { Thickness } \\
(\mathrm{m})\end{array}$ & $\begin{array}{l}\text { Unit } \\
\text { weight } \\
\left(\mathrm{kN} / \mathrm{m}^{3}\right)\end{array}$ & $\begin{array}{l}\text { UCS } \\
(\mathrm{MPa})\end{array}$ & $\begin{array}{l}\text { Elastic } \\
\text { modulus } \\
(\mathrm{GPa})\end{array}$ & $\begin{array}{l}\text { Poisson's } \\
\text { ratio }\end{array}$ & $\begin{array}{l}\text { Angle of } \\
\text { internal } \\
\text { friction }\left({ }^{\circ}\right)\end{array}$ & $\begin{array}{l}\text { Cohesion } \\
\text { strength } \\
(\mathrm{MPa})\end{array}$ & $\begin{array}{l}\text { Bulk } \\
\text { modulus } \\
(\mathrm{GPa})\end{array}$ & $\begin{array}{l}\text { Shear } \\
\text { modulus } \\
(\mathrm{GPa})\end{array}$ \\
\hline Soil & 150.0 & 21.0 & 4.8 & 0.056 & 0.29 & 20 & 0.05 & 0.04 \\
Bottom clay & 6.0 & 21.0 & 3.2 & 0.218 & 0.32 & 32 & 0.12 & 0.20 & 0.02 \\
Fine sandstone & 25.0 & 26.0 & 24.0 & 2.20 & 0.24 & 37 & 6.90 & 1.41 \\
Mudstone & 3.0 & 25.0 & 5.7 & 0.354 & 0.35 & 33 & 4.30 & 0.40 & 0.89 \\
Coal & 8.4 & 22.0 & 8.45 & 1.32 & 0.29 & 32 & 2.60 & 1.05 \\
Sandstone & 30.6 & 27.0 & 21.0 & 1.15 & 0.30 & 38 & 7.45 & 1.00 & 0.51 \\
Paste backfill material & 2.2 & 18.5 & $0.29-1.12$ & $0.40-2.76$ & 0.34 & $14.3-17.5$ & $0.21-0.65$ & $0.40-3.00$ & $0.20-1.00$ \\
\hline
\end{tabular}

the wide strips are each divided into 8 narrow strips with a width of $3.4 \mathrm{~m}$. Therefore, there are a total of 8 mining cycles, and a coal pillar with a width of $3.4 \mathrm{~m}$ was excavated and backfilled for each step. A narrow strip was exploited at a distance of $27.2 \mathrm{~m}$ from the previous narrow strip, which was backfilled at the same time. Then, the newly mined out narrow strip would not disturb the previous backfill so that there is time for intermittent filling in order for the backfill to maintain self-stability. The stable coal pillars beside the backfill along the panel in the advancing direction provide significant lateral restraint to the backfill, and the coal pillars and backfill support the overburden pressure together during the mining process.

\section{Stress evolution during intermittent cut-and-fill mining from numerical simulation}

During intermittent cut-and-fill mining, the overburden stress is jointly supported by the coal pillars and the backfill. The size of the coal pillars and backfill varies during the process of intermittent cut-and-fill mining. Therefore, there will be interactions between the coal pillars and backfill during the mining process, which are as follows: (1) The backfill becomes part of the geological formation and integrates with the formation; vertical compression and horizontal expansion are produced due to the overlying strata pressure. Then, the backfill induces lateral restraint to the coal pillars; (2) the vertically compressed coal pillars resultant of the pressure from the overlying strata can restrain the lateral deformation of the backfill; and (3) interactions between the coal pillars and backfill will reduce the stress concentration on the coal pillars and walls due to the stress transformation of the coal pillars to the backfill.

The intermittent cut-and-fill mining with a mining thickness of $2.2 \mathrm{~m}$ was carried out in the second slice after longwall excavation mining disturbance of the first slice with a mining thickness of $1.8 \mathrm{~m}$. Figure 10 shows the evolution of stress in the coal pillars and the backfill from the numerical simulation during the intermittent cut-and- fill mining process of the second slice. The stress concentrated on the two sides of the panel after the first slice mining disturbance with a factor of 4.5. However, this phenomenon does not aggravate during the mining process of second slice. The stress in the first strip is minimal so that the backfill in the goaf bears a low load of the overburden strata and the stress concentration in the coal pillars with a factor of 1.36. The load on the backfill increases slowly, and a maximum stress concentration factor of 1.48 is found in the center of the panel during the seventh mining cycle. However, the coal pillars still maintain stability due to the lateral restraint of the backfill.

The intermittent filling time will maintain the self-stability of the backfill, and then the first-filled body will carry a larger load than the last-filled body, that is, the first-filled body supports the pressure from the subsequently filled body. Only the backfill is left in the goaf to support the overburden strata after the mining is finished, and the stress in the goaf is approximate to that of the surrounding rocks. Mining disturbance has little effect on the overburden strata when the goaf is stable. Moreover, when the filling is carried out more rapidly, there will be a greater load on the backfill, thus resulting in less stress on the pillars and wall. This indicates that intermittent cut-and-fill ensures the stability of the coal pillars during the mining process, which is significant for mining safety under thin bedrocks and sand aquifers.

\section{Comparison of stress by different mining methods from numerical simulation}

After a longwall mining disturbance in the first slice, the stress due to longwall mining, continuous filling mining and intermittent cut-and-fill mining in the second slice were all simulated in the numerical simulation process in order to depict the stress distribution in the panel. Figure 11 shows the stress in the panel by using three mining methods. There is more stress concentration in the coal walls with longwall excavation followed closely by continuous filling, which would lead to the failure of the coal 


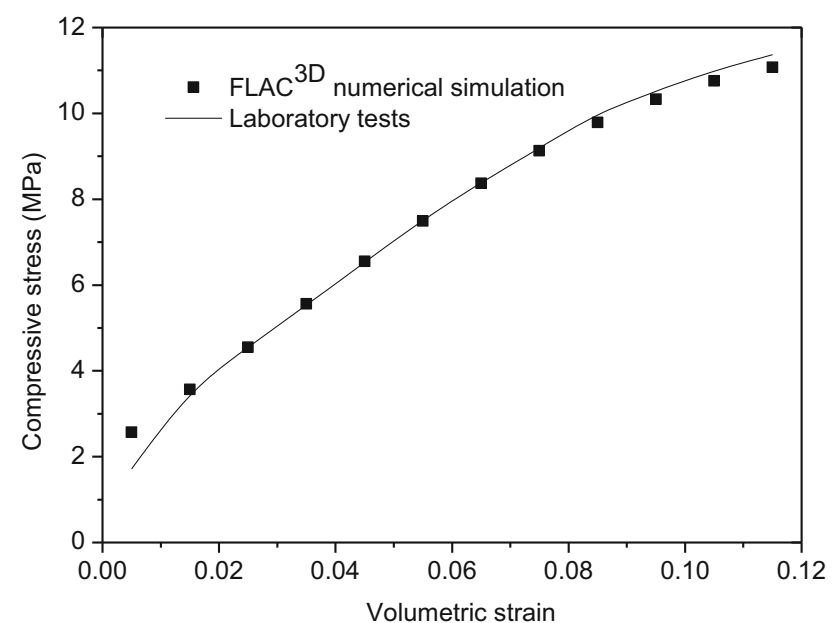

(a)

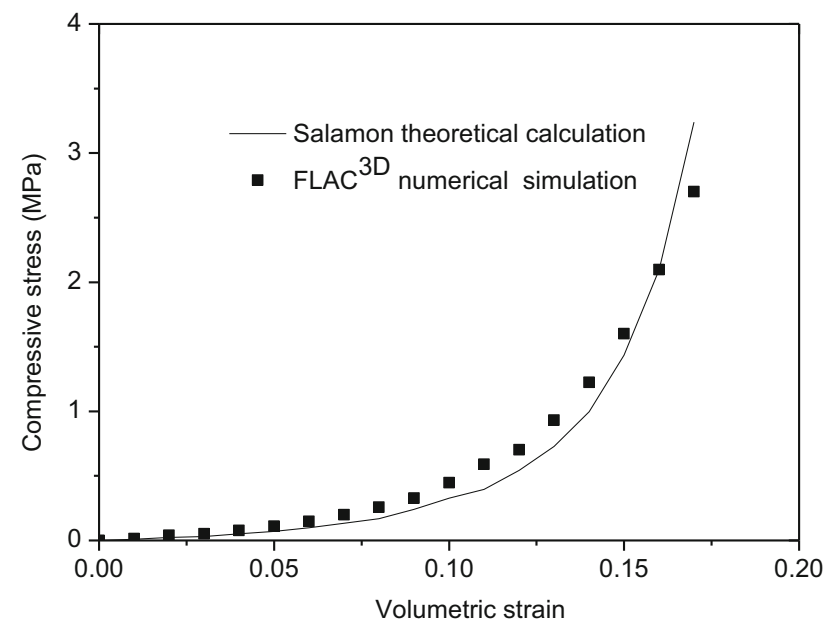

(b)

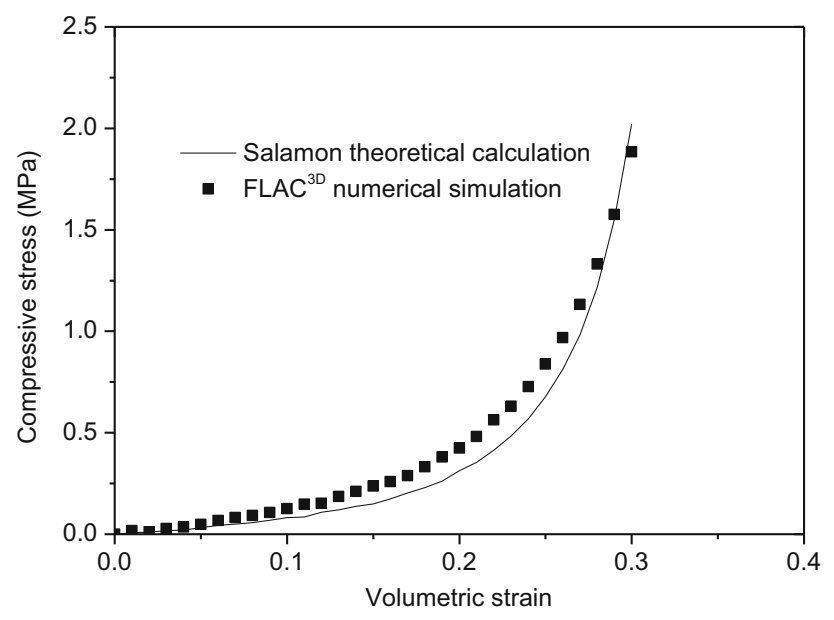

(c)

Fig. 9 Fitted curve of stress and strain in unit of paste backfill material and caving zone. a Paste backfill material; b first slice of longwall excavation; $\mathbf{c}$ second slice of longwall excavation pillars, and as a result, the mining process is unsafe. Moreover, the stress concentration factor with intermittent cut-and-fill mining is 3.9 which is reduced by 23.5 and $7.1 \%$, respectively, compared to 5.1 for longwall excavation and 4.2 for continuous filling.

During the longwall excavation process, there is the release of stress in the mined out area where the stress is much smaller than that in the surrounding rock. The stress concentration with a factor of 5.1 in the coal walls on both sides of the panel is so serious that a large area of the roof might possibly collapse due to mining disturbance and even lead to water and sand inrush.

When the continuous filling is carried out in the panel, the load on the backfill is gradually increased as the mining is carried out, while there is a smaller factor in the stress concentration of 4.2 in the coal walls on both sides of the panel. Moreover, the stress in the center of the panel is larger than that on both sides of the panel due to longwall excavation.

During the intermittent cut-and-fill mining, there is time for the consolidation of the backfill and the subsidence induced by the deformation of the coal seam roof due to the intermittent filling time. Therefore, the deformation of the coal seam roof is constant and slow with a progressive and small disturbance. The stress concentration in the backfill is weak, and the rate of subsidence due to the deformation of the roof is slow. However, there is already disturbance before the previous round of backfilling is carried out due to continuous filling, so that the bearing capacity of the backfill is weaker than that with intermittent cut-and-fill mining.

Figure 12 shows the stress distribution on a section along the direction of $Y=170 \mathrm{~m}$ from the 3D modeling after the mining process is carried out. It shows the stress on a cross section which is distributed in peaks and valleys, of which the peaks are characterized by larger stresses, while the valleys by smaller stresses. Longwall mining has aggravated the strata deformation that a most serious stress concentration occurred on the coal walls in the two sides of the panel. Continuous filling mining has controlled the deformation of the strata and reduced the stress concentration. Furthermore, intermittent cut-and-fill mining has the best effect of controlling the strata deformation that can mitigate overburden failure and subsidence.

Figure $13 \mathrm{a}-\mathrm{c}$ shows the maximum principal stress contours of the surrounding rock after longwall excavation, continuous filling and intermittent cut-and-fill mining. In line with the mining process, the stress concentration expands upward and is developed at both sides. Finally, the shape of the maximum principal stress contour is like an "arch" induced by longwall excavation, and the different 
Table 6 Simulation parameters for paste backfill material and caving zone

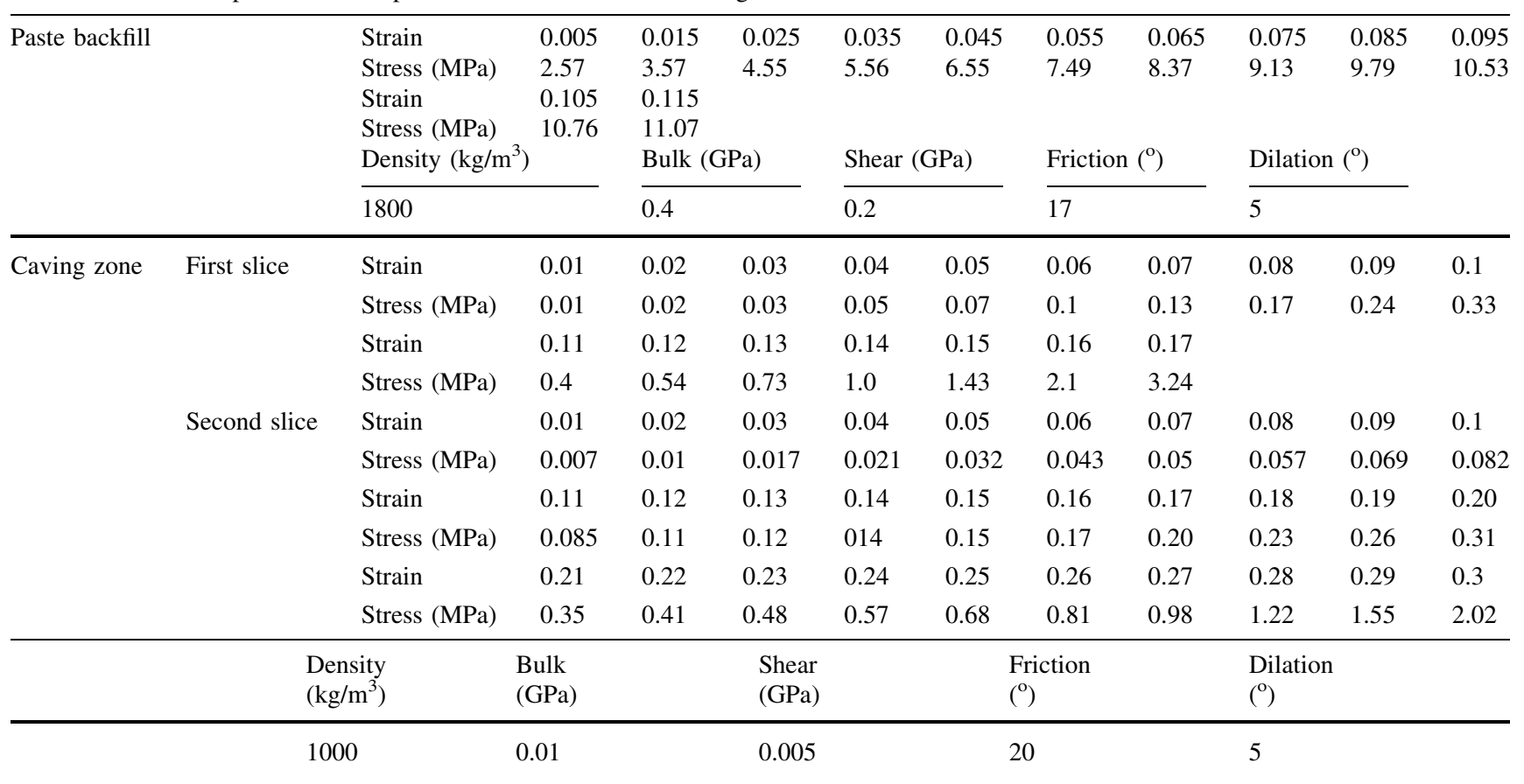

bands represent the intermittent filling, but the value of the stress in the coal walls on the two sides of the panel is larger than that in the center of the panel with continuous filling. Furthermore, the stress value induced by intermittent cut-and-fill mining is reduced by 28.6 and $9.1 \%$ compared to that with longwall excavation and continuous filling.

Figure $13 \mathrm{~d}-\mathrm{f}$ shows the minimum principal stress distribution. The stress redistribution expands to the boundary of the panel, and the stress value in the coal walls on both sides of the panel is larger than that in the center of the panel. Moreover, intermittent cut-and-fill mining induces the lowest minimum principal stress which is reduced by 22.7 and $3.7 \%$ compared to longwall excavation and continuous filling. All of the results indicate that there is the least disturbance from intermittent cut-and-fill mining which is favorable for mining safety.

\section{Comparison of stress by different mining methods verified by field measurements}

Panel S01 is the first panel in the sixth district in the Taiping Coal Mine. Longwall excavation with a mining thickness of $1.8 \mathrm{~m}$ in the first slice and paste backfill mining with a mining thickness of $2.2 \mathrm{~m}$ in the second slice were carried out. The hydraulic supports' pressures have been measured in the first and second slices which could characterize the stress distribution in the panel. Twenty observation points were designed in the panel and gate roads with a distance of 4 hydraulic supports.
Figure 14 shows that the front and behind support pressures vary with the mining process by using longwall excavation and filling mining. The front and behind support pressure variations are basically identical during the mining process. Paste backfill in the second slice has not caused a large increase in the support pressure; conversely, a decreasing trend occurred in the second slice. However, the support pressure distribution is more stable and uniform by using paste backfill mining than that by using longwall excavation. Furthermore, the paste backfill produces a smaller maximum support pressure of $29.3 \mathrm{MPa}$ than that produced by longwall excavation at a value of $32.2 \mathrm{MPa}$, which has a smaller mining disturbance and is more conducive to mining safety.

The results show that the characteristics of stress variation based on numerical simulation are consistent with that from the field measurements in the same area, and both results imply that filling mining can reduce mining disturbance and stress concentration. As stated, the stress concentration coefficient is the smallest by using the intermittent cut-and-fill mining compared to longwall excavation and continuous filling.

\section{Overburden failure and verification by the field measurements}

Scale model testing of overburden failure

The caving zone was induced by rupturing, cracking and caving of the roof strata during the excavation of the first 

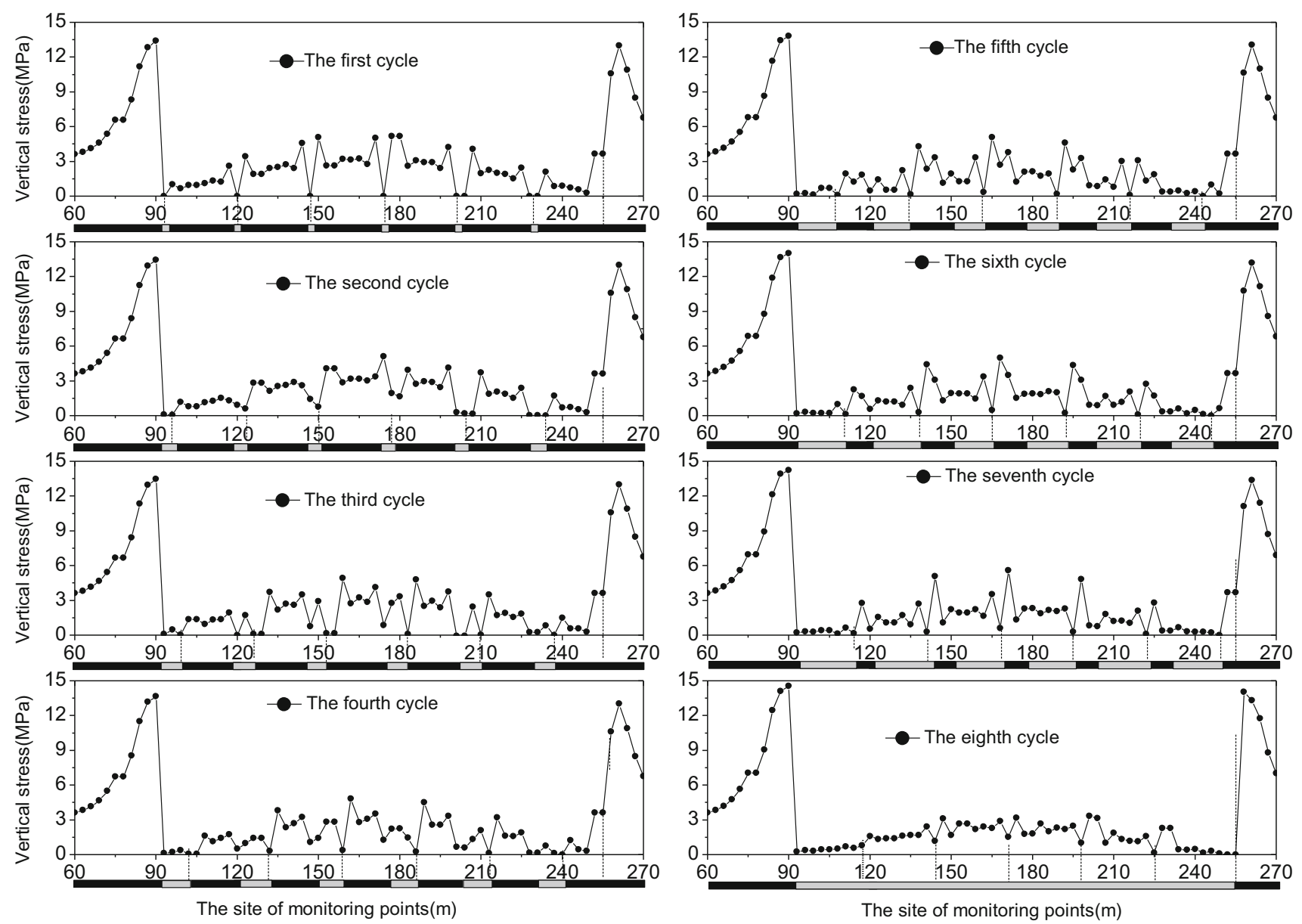

Fig. 10 Evolution of stress of coal pillars and backfill

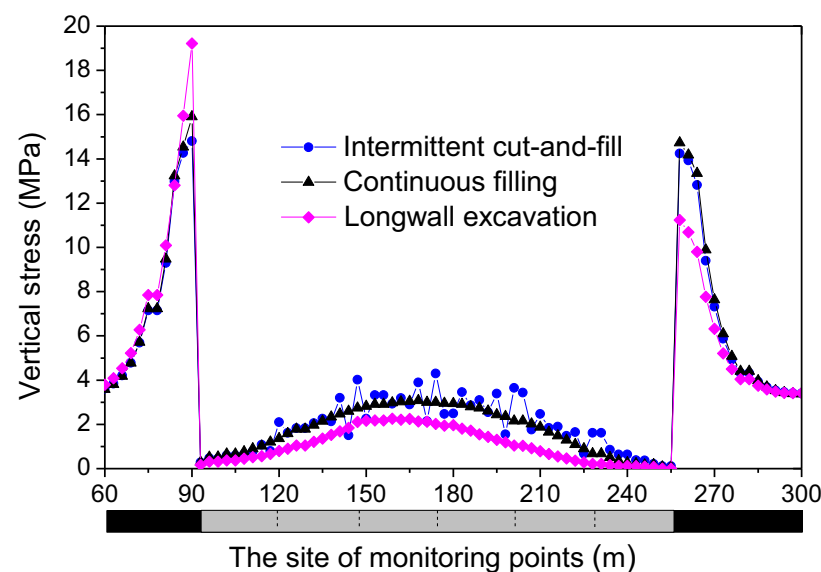

After the excavation was completed, the fractures in the caving zone were basically compacted, and then the maximum height of the caving and water-conducting fractured zones was 6.0 and $17.5 \mathrm{~m}$, respectively, which formed a saddle-like shape (Fig. 15a). This is due to the stress concentration in the coal walls on both sides of the panel, and then the edges of the panel were able to support only minimal overburden stress. The stress in the center of the panel was higher, and strata collapse was more serious than that on the edges.

The second slice was extracted in steps with a distance of $40 \mathrm{~m}$ after the first slice was drawn and conditions stabilized. Moreover, intermittent cut-and-fill mining and continuous filling were both used with two scale models in mining the second slice. In line with the mining process, the overburden failure in the expanded region is slightly deformed and the compacted fractures do not extend any further, and only a few microfractures are produced and some developed along the previous fractures induced by longwall excavation. Due to the support provided by the backfill which has self-stability resultant of adequate time for consolidation during intermittent cut- 
Fig. 12 Vertical stress distribution on a cross section of $Y=170 \mathrm{~m}$ in panel.

a Intermittent cut-and-fill mining of the second slice; b continuous filling mining of the second slice; c longwall excavation mining of the second slice

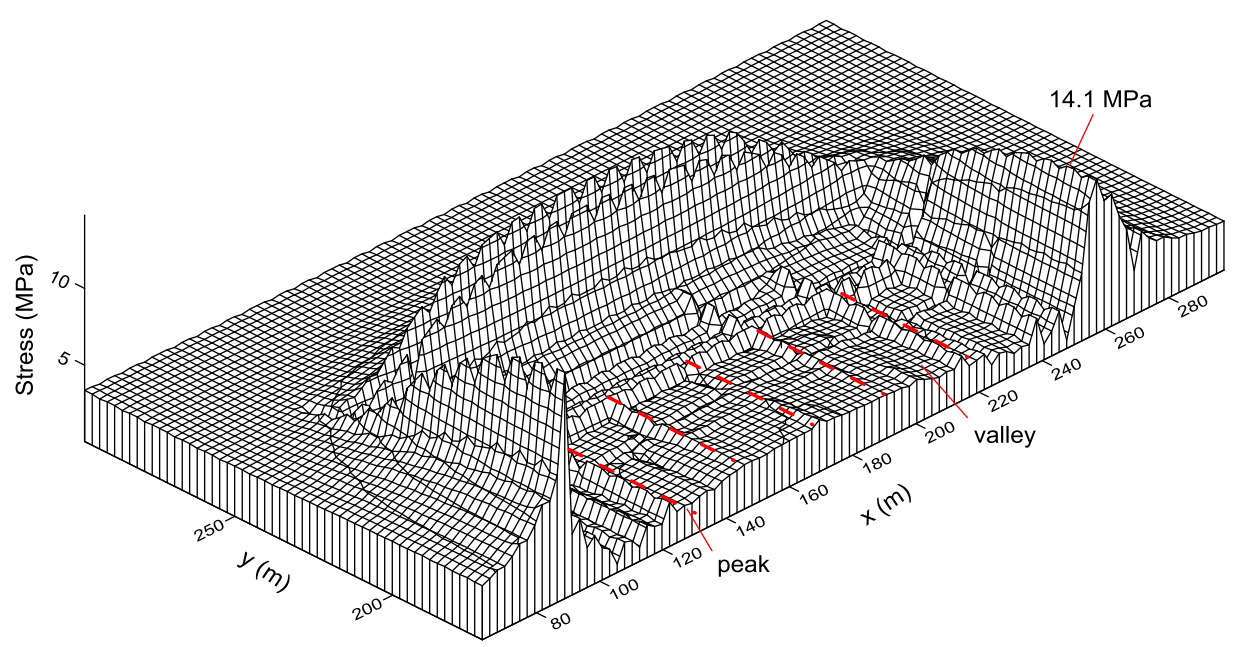

(a)

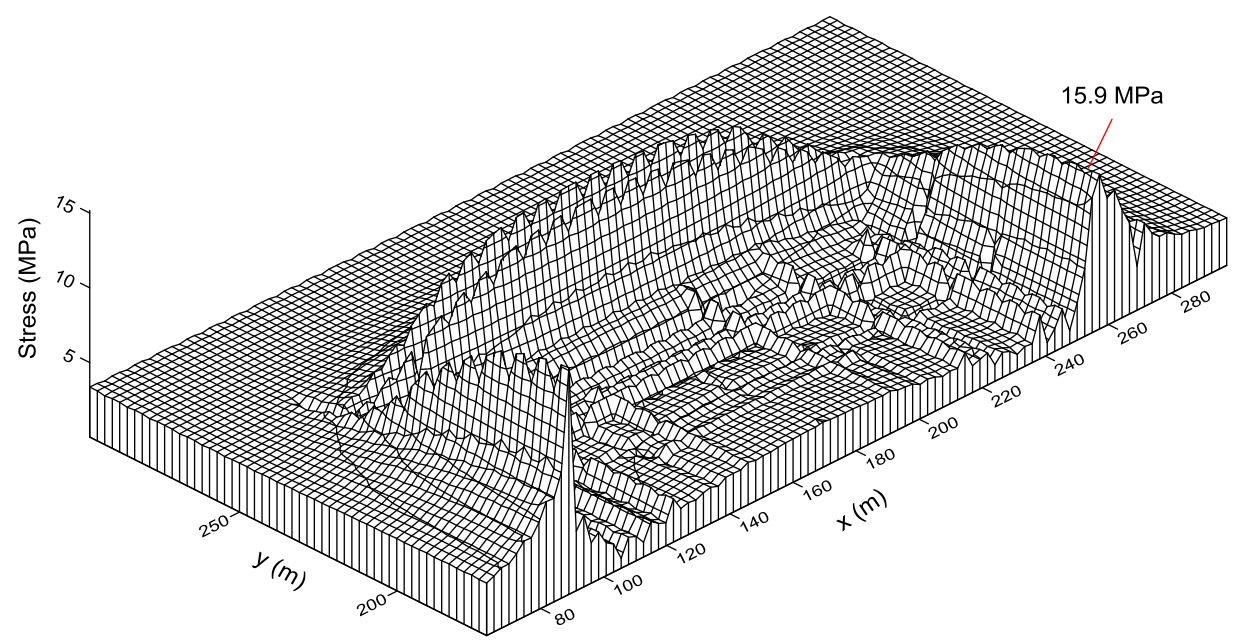

(b)

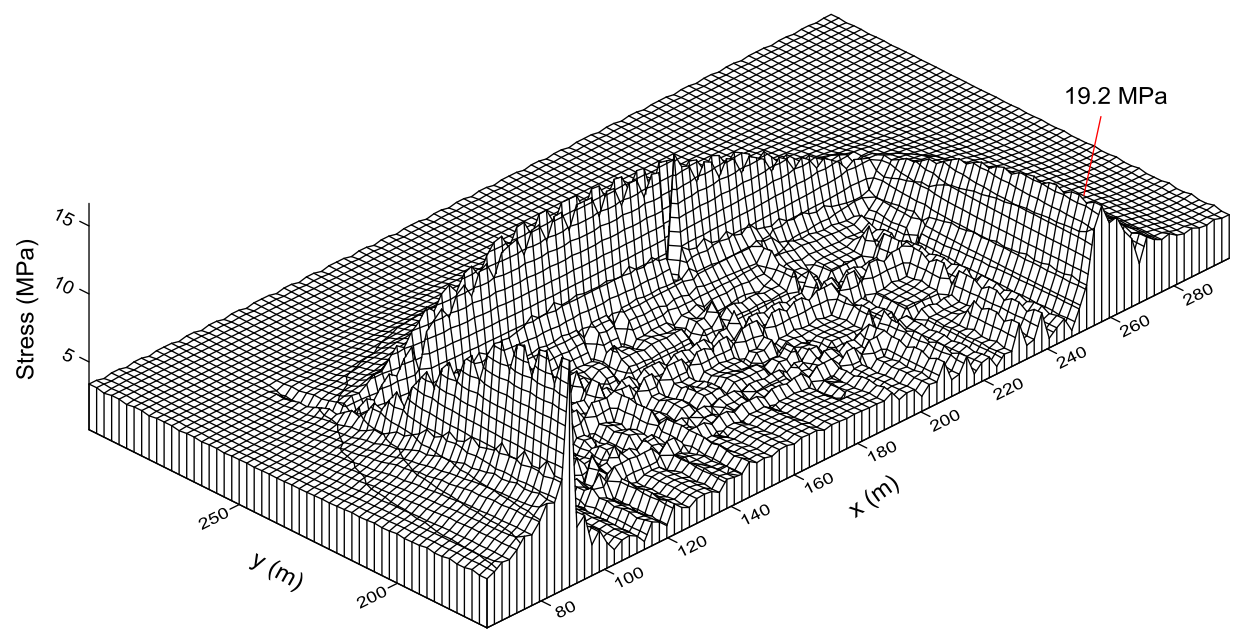

(c) 


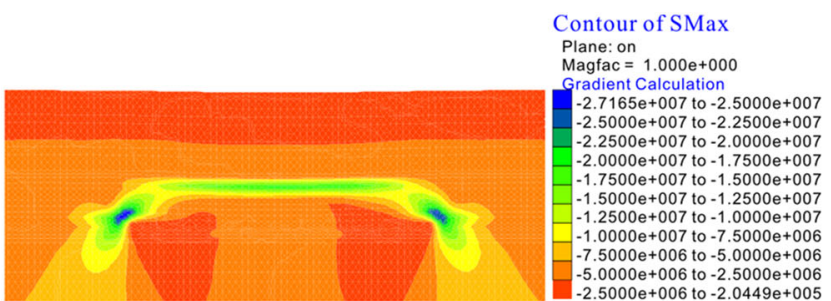

(a)

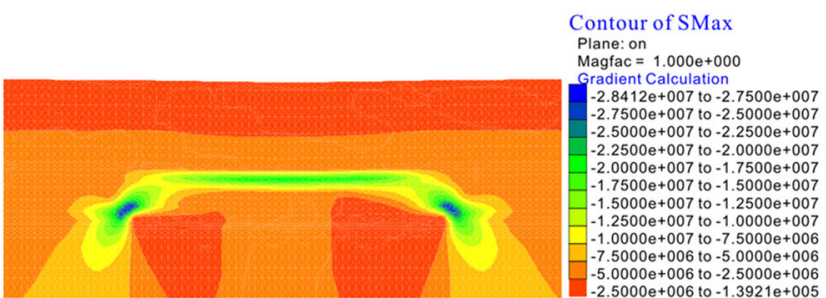

(c)

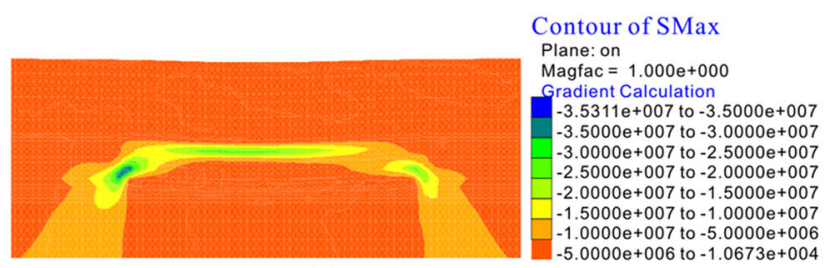

(e)

Fig. 13 Maximum and minimum principal stress contours of surrounding rock. a Maximum principal stress with intermittent cut-andfill; b maximum principal stress with continuous filling; $\mathbf{c}$ maximum principal stress with longwall excavation; $\mathbf{d}$ minimum principal stress

and-fill mining, the settlement of this backfill is less than that by continuous filling. Moreover, overburden failure is mitigated by backfill mining. The height of the waterconducting fractured zone is 19.5 and $21.2 \mathrm{~m}$, respectively, by intermittent cut-and-fill mining and continuous filling, which means that the disturbance produced by the former is smaller than that by the latter. Figure 15b, c shows that the water-conducting fractured zone has increased somewhat and also takes the shape of a saddle. The heights are minimally increased compared to those induced by the longwall excavation. Moreover, there is no caving zone in the expanded zone and the caving zone induced by longwall excavation of the first slice does not extend upward. Figure 16 shows that the water-conducting fractured zone has slightly increased, but the caving zone hardly grew during intermittent cut-and-fill and continuous filling.

\section{Numerical simulation of overburden failure}

Figure 17 shows the plastic zone distribution induced by longwall excavation, continuous filling and intermittent cut-and-fill mining. The plastic zone extends upward along the sides of the panel with the shape of a saddle induced by

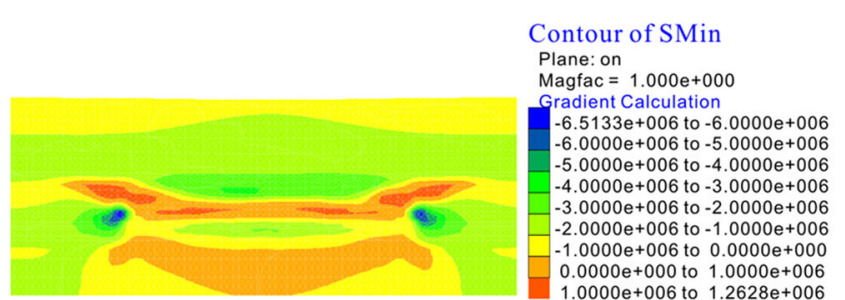

(b)

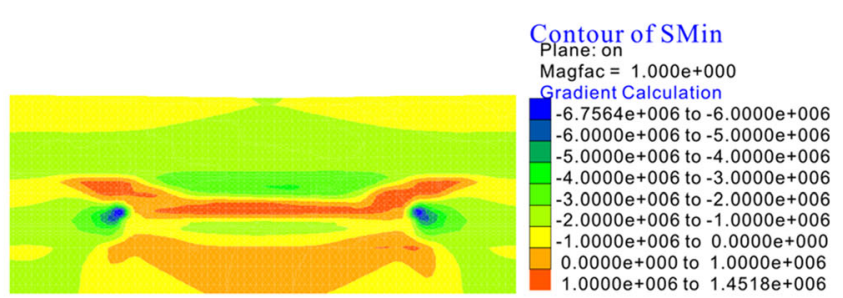

(d)

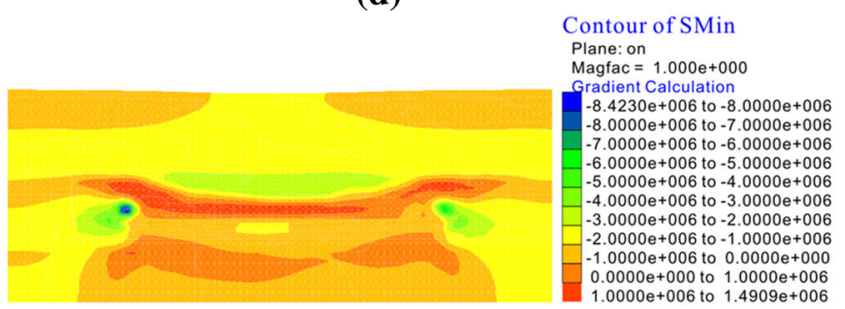

(f)

with intermittent cut-and-fill; e minimum principal stress with continuous filling; $\mathbf{f}$ minimum principal stress with longwall excavation

longwall excavation. After longwall excavation mining disturbance of the first slice, the size of the plastic zone induced by continuous filling and intermittent cut-and-fill mining of the second slice has little expansion, and the integrity of the surrounding rock by using the intermittent cut-and-fill remains better than that induced by continuous filling. However, the surrounding rock has almost entirely deformed and failed due to longwall excavation in the second slice. Furthermore, the plastic zone has discontinuities, mainly from tensile failure. The height of the water-conducting fractured zone induced by filling mining of the second slice does not increase seriously, and the intermittent cut-and-fill mining disturbance is smaller than that induced by continuous filling. There is a caving zone with a height of $7.2 \mathrm{~m}$ due to longwall excavation, but no caving zone is formed by the other two backfill mining methods. However, the safety mining has already been achieved in the first slice of the Panel S01 in March 2011, and the water-conducting fractured zone has not propagated into the aquifer of the unconsolidated Neogene layers. All of the results indicate that the use of intermittent cut-and-fill mining to mitigate overburden failure is the most effective, which is best for coal mining under sand aquifers. 


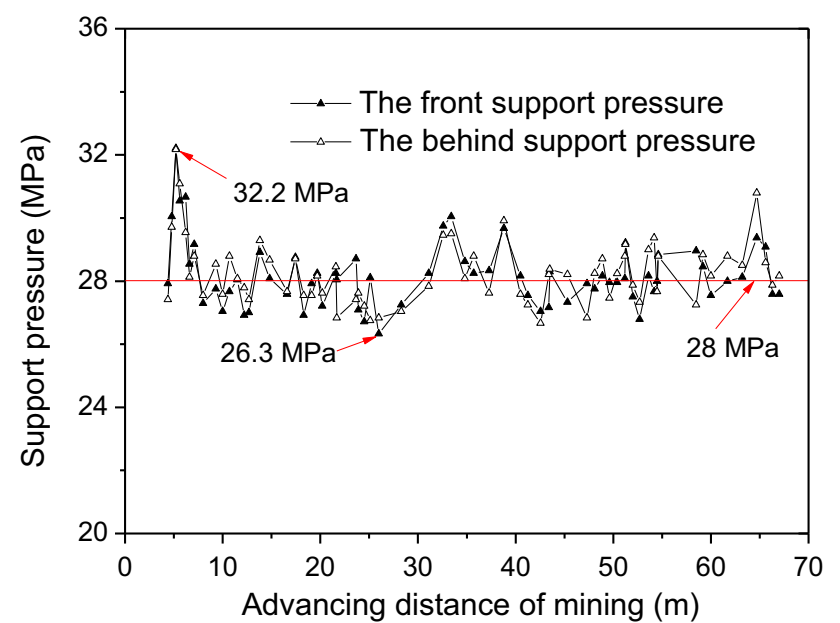

(a)

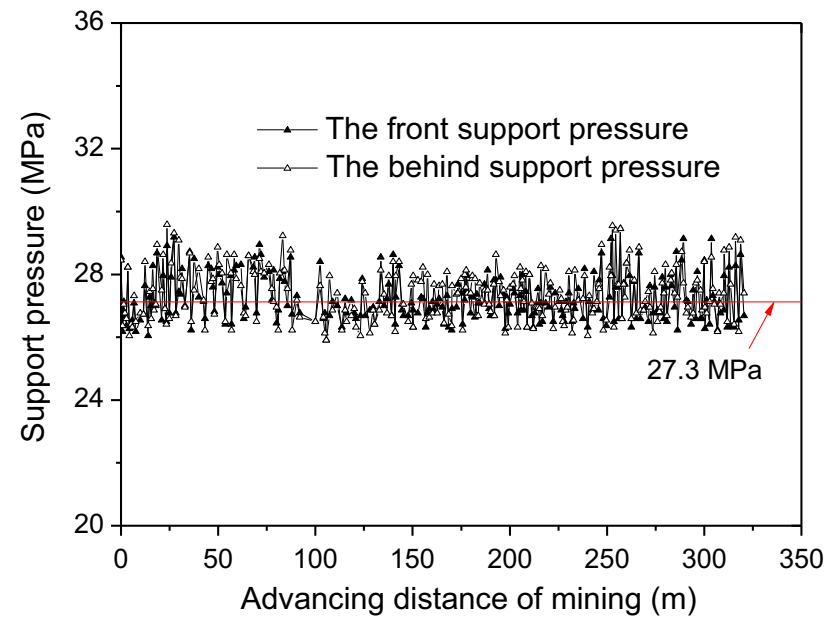

(b)

Fig. 14 Support pressure variation with mining process. a Longwall excavation in the first slice; $\mathbf{b}$ paste backfill mining in the second slice

\section{Overburden failure verified by the field measurements}

Panel 8311 adjacent to the Panel S01 was selected for overburden failure measurements induced by paste backfill mining. The bottom slice with the height of $2.2 \mathrm{~m}$ by using the paste backfill mining in the Panel 8311 has achieved a safe mining in 2008. The engineering geological and hydrogeological conditions are similar to that in Panel S01.

The above-mentioned water loss method was used to measure overburden failure with four underground boreholes, one of which was designed and carried out before mining and other three after mining in order to measure the water loss. Results showed that the maximum height of water-conducting fractured zone is $6.93 \mathrm{~m}$ above the coal seam roof and the height ratio of the height of water-conducting fractured zone against the mining thickness of $2.2 \mathrm{~m}$ is 3.15 . However, there is no caving zone formed by using the paste backfill mining. According to the former mining experiences in the Taiping Coal Mine, the heights of caving zone and water-conducting fractured zone by using longwall excavation in the first slice were no more than 6.0 and $17.0 \mathrm{~m}$, respectively. The height ratios of the caving and water-conducting fractured zones against the mining thickness of $1.8 \mathrm{~m}$ were no more than 3.33 and 9.44, respectively.

Table 7 shows the heights of overburden failure due to three mining methods. Furthermore, the paste backfill mining in the second slice with a thickness of $2.2 \mathrm{~m}$ just led to a slight increase in the water-conducting fractured zone with the maximum value of $21.2 \mathrm{~m}$ and no expansion in the caving zone. The scale model and numerical simulation provide a reasonable explanation of the field observations and imply that filling mining could mitigate overburden failure and the use of intermittent cut-and-fill mining is the most effective.

\section{Subsidence and verification by the field measurements}

The immediate roof caved into the goaf as longwall excavation progressed in that the subsidence value of the roof consistently increased due to the collapse resultant of the mining cycle. However, there is high compressibility in the backfilling that has just been completed so that a certain amount of compression will be produced due to the overburden pressure. Furthermore, the convergence of the roof and floor before backfilling and the area that has not been backfilled will provide room for roof subsidence which reduces the effects of subsidence compared to that induced by longwall excavation. Moreover, the intermittent filling time provides a buffer for the consolidation of the paste material and roof subsidence of the coal seam during intermittent cut-and-fill mining which causes continuous and constant minimal disturbance of the coal seam roof with slow rates of deformation compared to the use of continuous filling.

Figure 18a shows the roof subsidence with the use of longwall excavation, continuous filling and intermittent cut-and-fill mining based on scale model testing. The subsidence curves show the shape of a bilateral symmetric parabola with the smallest value of the maximum subsidence, $0.49 \mathrm{~m}$, with intermittent cut-and-fill in the second slice as opposed to longwall excavation with a maximum subsidence value of $1.37 \mathrm{~m}$ in the first slice and continuous filling with a maximum subsidence value of $0.58 \mathrm{~m}$ in the second slice, based on the results from the scale model testing. Moreover, the subsidence curves of the second slicing phase with backfill mining are flat with a slow rate of subsidence. This is because the space for roof subsidence induced by backfill mining is smaller than that by longwall excavation and the backfill provides a support 


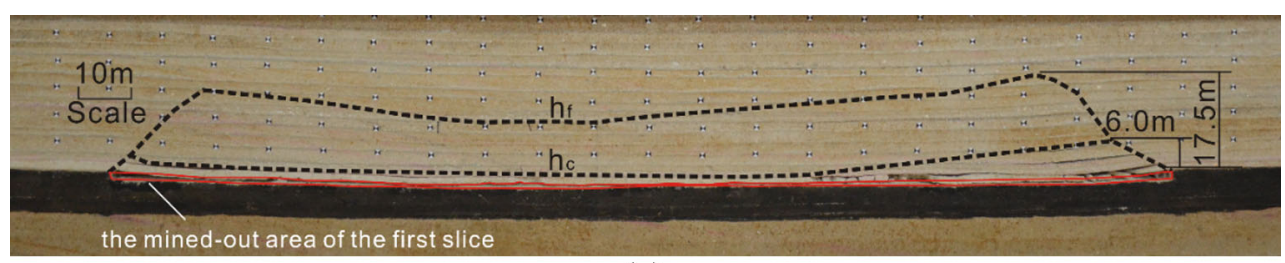

(a)

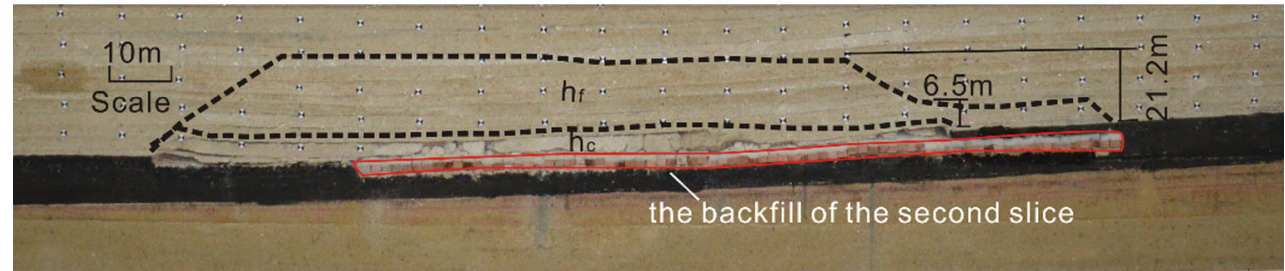

(b)

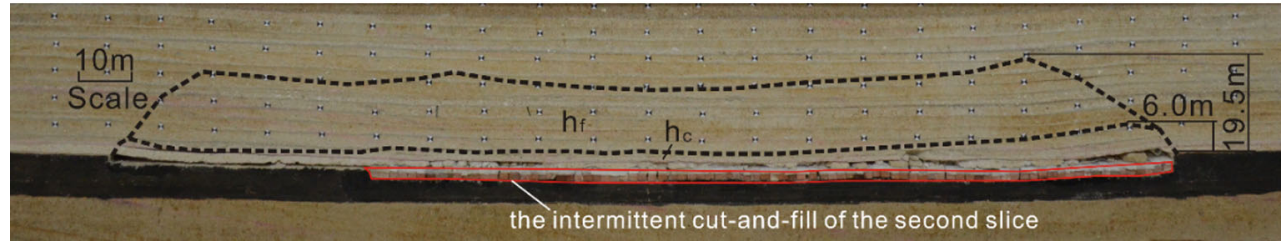

(c)

Fig. 15 Overburden failure by using three mining methods. $h_{\mathrm{c}}$ height of caving zone; $h_{\mathrm{f}}$ height of water-conducting fractured zone. a Longwall excavation; b continuous filling; $\mathbf{c}$ intermittent cut-and-fill

Fig. 16 Height of overburden failure after mining

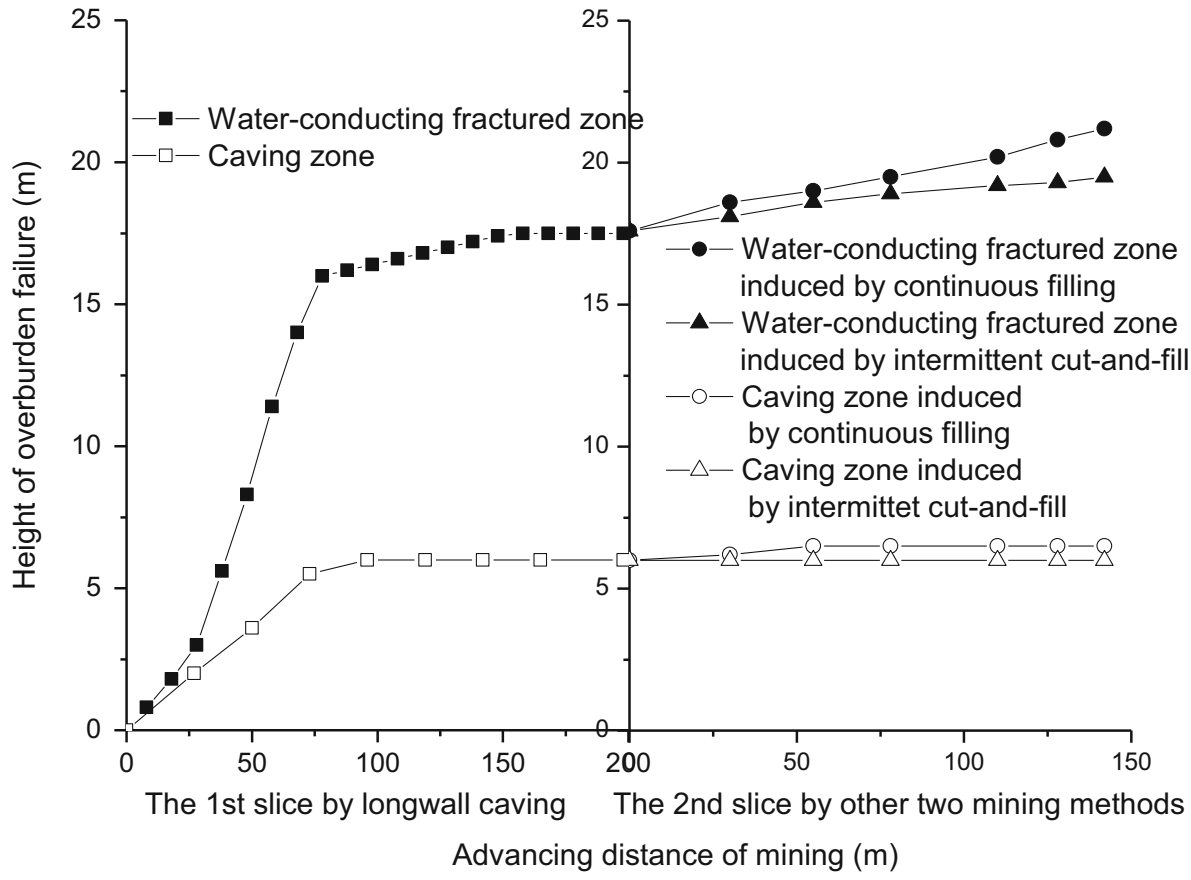

immediately, and also the interval provided by intermittent cut-and-fill mining can reduce the roof subsidence. These results indicate that intermittent cut-and-fill mining can effectively control roof subsidence compared to the other mining methods.

Figure $18 \mathrm{~b}$ shows the total subsidence curves of two slices by using the above-mentioned three mining methods.
After the mining of the first slice with longwall excavation, the maximum subsidence value was $1.6 \mathrm{~m}$ with a coefficient of 0.89 . When the second slice was mined out, the total maximum vertical displacement value of $2.17 \mathrm{~m}$ with intermittent cut-and-fill mining is the lowest, as opposed to longwall excavation with a maximum vertical displacement value of $3.51 \mathrm{~m}$ and continuous filling with a 


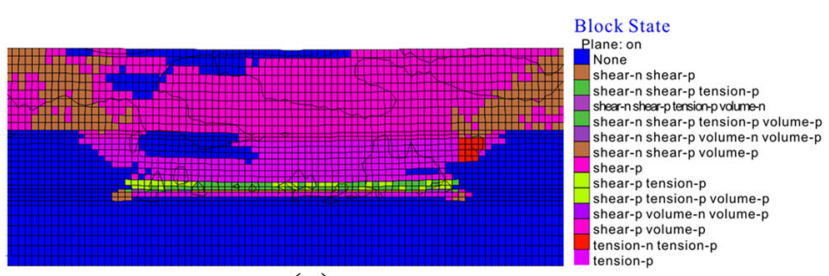

(a)

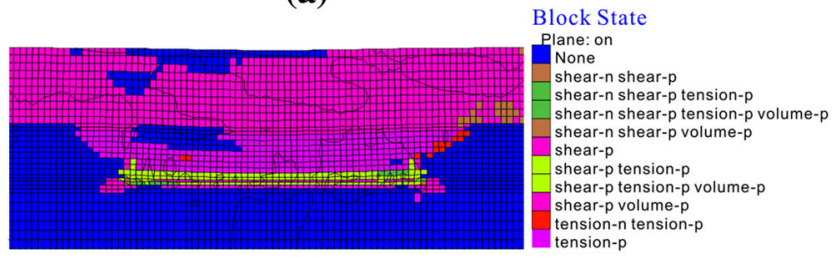

(c)

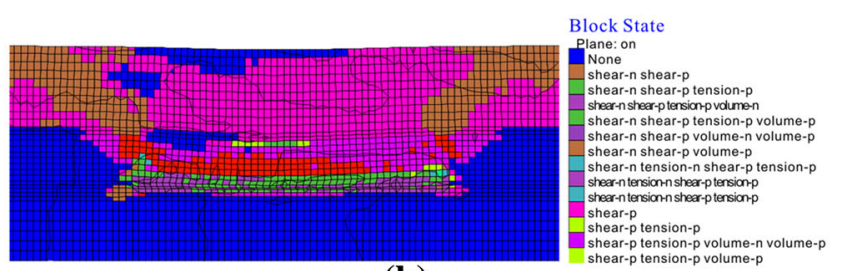

(b)

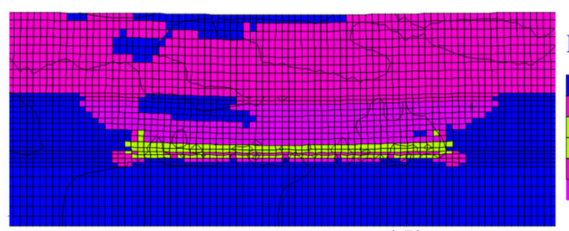

Block State

Plane: on

None
shear-p

shear-p tension-p

shear-p tension-p volume-p

shear- $p$ volume- $p$

tension-p

Fig. 17 Plastic zone distribution in the surrounding rock. a Longwall excavation of the first slice; b longwall excavation of the second slice; c continuous filling of the second slice; $\mathbf{d}$ intermittent cut-and-fill of the second slice

Table 7 Heights of overburden failure resulted from different techniques

\begin{tabular}{|c|c|c|c|c|c|c|c|c|c|c|c|}
\hline \multirow[t]{2}{*}{ Mining methods } & \multirow[t]{2}{*}{ Slice } & \multirow[t]{2}{*}{ Mining thickness $H(\mathrm{~m})$} & \multicolumn{3}{|c|}{ Scale model } & \multicolumn{3}{|c|}{ Numerical simulation } & \multicolumn{3}{|c|}{ Field measurements } \\
\hline & & & $H_{\mathrm{c}}(\mathrm{m})$ & $H_{\mathrm{f}}(\mathrm{m})$ & $H_{\mathrm{f}} / H$ & $H_{\mathrm{c}}(\mathrm{m})$ & $H_{\mathrm{f}}(\mathrm{m})$ & $H_{\mathrm{f}} / H$ & $H_{\mathrm{c}}(\mathrm{m})$ & $H_{\mathrm{f}}(\mathrm{m})$ & $H_{\mathrm{f}} / H$ \\
\hline \multirow[t]{2}{*}{ Longwall } & First & 1.8 & 6.0 & 17.5 & 9.72 & 7.2 & 18.0 & 10 & 6.0 & 17.0 & 9.44 \\
\hline & Second & 2.2 & - & - & - & $>19.0$ & $>27.0$ & - & - & - & - \\
\hline Continuous filling & Second & 2.2 & 6.0 & 21.2 & 5.28 & 7.2 & 22.0 & 5.5 & - & 6.93 & 3.15 \\
\hline Intermittent cut-and-fill & Second & 2.2 & 6.0 & 19.5 & 4.86 & 7.2 & 19.2 & 4.8 & - & - & - \\
\hline
\end{tabular}

$H_{\mathrm{c}}$ height of caving zone; $H_{\mathrm{f}}$ height of water-flowing fractured zone; - not applicable

maximum vertical displacement value of $2.37 \mathrm{~m}$. Furthermore, only the subsidence of second slice is considered and a maximum subsidence of $0.53 \mathrm{~m}$ with intermittent cutand-fill is also the smallest, as opposed to continuous filling and longwall excavation with a maximum subsidence of 0.66 and $1.92 \mathrm{~m}$, respectively. Results showed a good agreement with the scale model testing. Figure 19 shows the vertical displacement inside the rock mass induced by longwall excavation, continuous filling and intermittent cut-and-fill mining based on the numerical simulation. The subsidence of the overlying strata shows that the maximum vertical displacement is near the middle of the panel and lower vertical displacement at the two ends of the panel; close proximity to the ground results in lower vertical displacement.

Measurements for the subsidence of longwall excavation and paste backfill in the Panel S01 were completed in November 2011 and April 2013, respectively. Results showed that the maximum subsidence of longwall excavation and paste backfill was 1.6 and $0.31 \mathrm{~m}$, respectively, and the subsidence coefficients were 0.89 and 0.14 , respectively. However, the subsidence coefficients of continuous filling and intermittent cut-and-fill are 0.22 and 0.26 , respectively, based on the scale model testing, and 0.24 and 0.3 based on the numerical simulation, respectively. Additionally, the subsidence coefficient was not more than 0.34 according to the backfill mining experience of the Taiping Coal Mine, which well verified the results of scale model testing and numerical simulation.

Table 8 shows the subsidences by using three mining methods in Panel S01. All of the results indicate that filling mining could better control the roof subsidence and mitigate overburden failure and the intermittent cut-and-fill is the most effective method.

\section{Discussion}

The backfill material used in the Taiping Coal Mine has a strong consolidation capability and high early strength compared to other cementing materials, and a strain hardening process was generated at low confining pressures that can satisfy the requirements of the strength of the backfill during coal mining under sand aquifers. Moreover, the major construction aggregate of the paste material, which is sand, is abundantly found by the Sihe River in this region. Coal pillars and backfill maintain stability during the mining process, and the stress concentration is reduced with the stress transformation of the coal pillars to the backfill as compared to longwall excavation and 
The site of monitoring points $(\mathrm{m})$

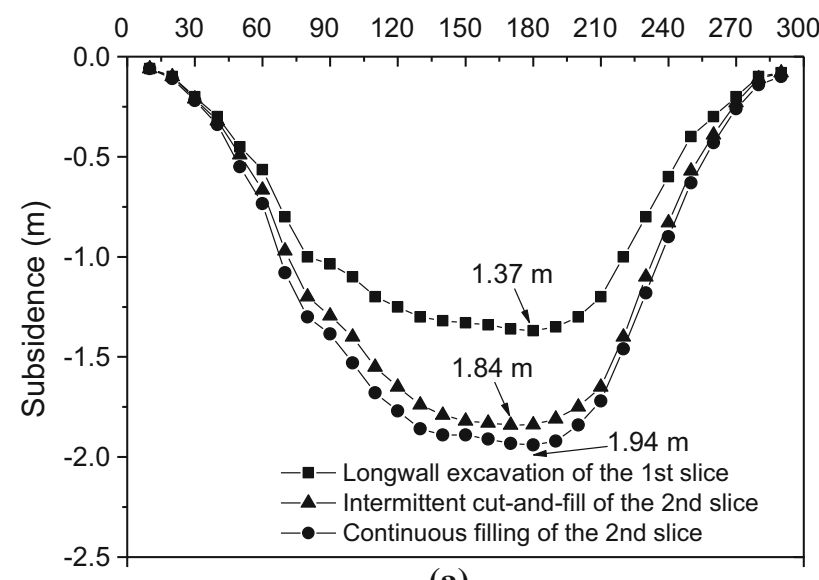

(a)

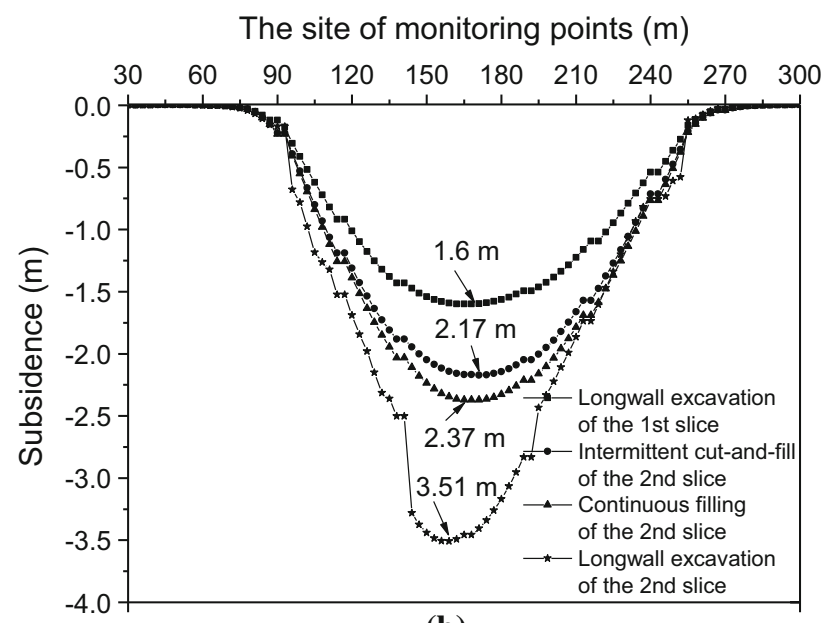

(b)

Fig. 18 Subsidence curves of scale model testing and numerical simulation. a Scale model tests; b numerical simulation

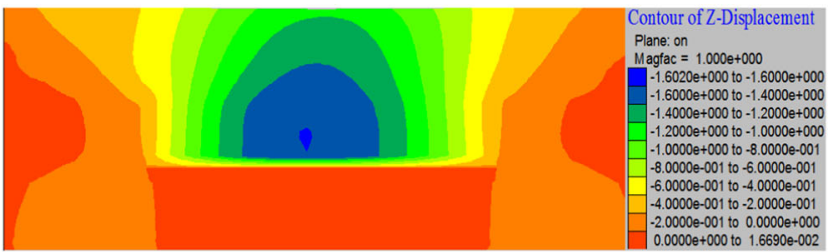

(a)

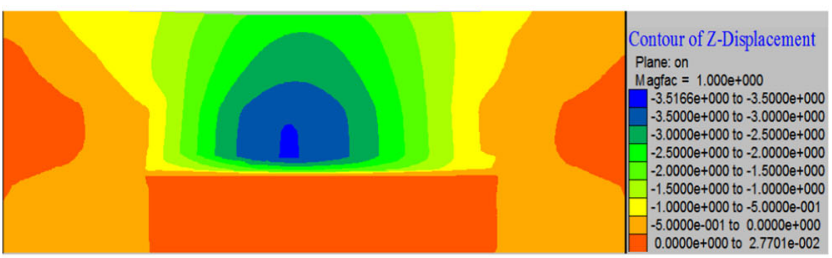

(b) continuous filling. Moreover, the interval provided by intermittent cut-and-fill mining improves the self-stability of the backfill and reduces the rate of roof subsidence, so that the height of the water-conducting fractured zone and roof subsidence induced by intermittent cut-and-fill mining are the lowest compared to longwall excavation and continuous filling, which indicates the mitigating overburden failure and reducing roof subsidence by intermittent cutand-fill mining is the most effective. Therefore, control over subsidence-induced overburden failure during coal mining under sand aquifers has been achieved with success.

Several coal mines in China have used backfill mining methods similar to that proposed in this paper and shown optimal results in mitigating overburden failure and subsidence and improving the coal recovery rate (Guo et al. 2007; Yu and Wang 2011). The method of three-step mining for ground subsidence control (strip mining, goaf grouting and filling-strip pillar mining) proposed by Guo showed that the final ground subsidence factor can be controlled at 0.25 and the coal recovery will be $80-90 \%$. Moreover, the use of gangue backfill in a flat coal seam with a thickness of $5 \mathrm{~m}$ in the Baoyuan Coal Mine indicates that the bearing body can resist against high stress and the overlying strata maintain a quadratically stable condition. The safety factor $F_{\mathrm{s}}=1.36$ of the bearing body which contains "bearing rock strata + gangue fill support body" proves that the stope is placed in a stable condition.

Furthermore, the method proposed in this paper demonstrates that intermittent cut-and-fill mining not only mitigates overburden failure and surface subsidence, but also improves the coal recovery rate. The extraction of the slice using this method under the panels after using

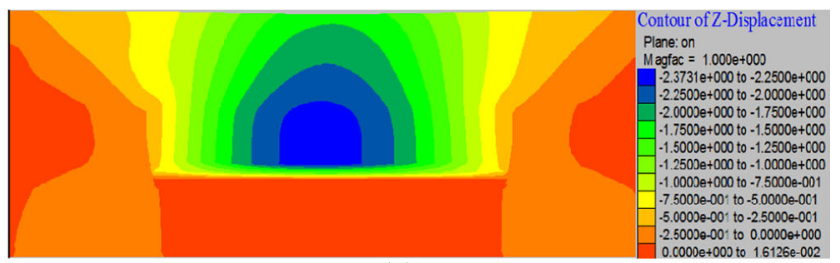

(c)

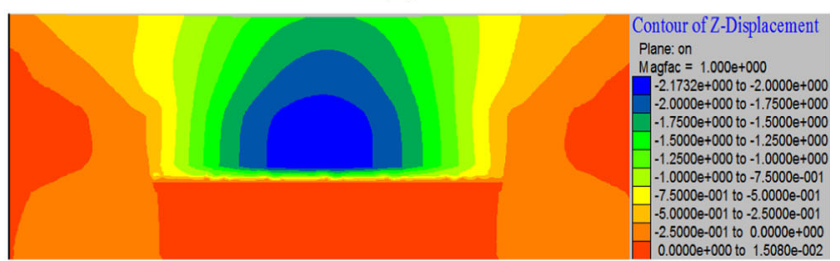

(d)

Fig. 19 Vertical displacement inside the rock mass. a Longwall excavation of the first slice; b longwall excavation of the second slice; c continuous filling of the second slice; $\mathbf{d}$ intermittent cut-and-fill of the second slice 
Table 8 Subsidences resulted from different techniques in Panel S01

\begin{tabular}{|c|c|c|c|c|c|c|c|c|}
\hline \multirow[t]{2}{*}{ Mining methods } & \multirow[t]{2}{*}{ Slice } & \multirow[t]{2}{*}{ Mining thickness $H(\mathrm{~m})$} & \multicolumn{2}{|l|}{ Scale model } & \multicolumn{2}{|c|}{ Numerical simulation } & \multicolumn{2}{|l|}{ Field measurements } \\
\hline & & & Subsidence $S(\mathrm{~m})$ & $S / H$ & Subsidence $S(\mathrm{~m})$ & $S / H$ & Subsidence $S(\mathrm{~m})$ & $S / H$ \\
\hline \multirow[t]{2}{*}{ Longwall } & First & 1.8 & 1.37 & 0.76 & 1.6 & 0.89 & 1.6 & 0.89 \\
\hline & Second & 2.2 & - & - & 1.92 & 0.87 & - & - \\
\hline Continuous filling & Second & 2.2 & 0.58 & 0.26 & 0.66 & 0.30 & 0.31 & 0.14 \\
\hline Intermittent cut-and-fill & Second & 2.2 & 0.49 & 0.22 & 0.53 & 0.24 & - & - \\
\hline
\end{tabular}

$S$ subsidence; $H$ mining thickness; - not applicable

longwall excavation can prevent the water-conducting fractured zone from penetrating the sand aquifers.

The results of this paper will provide a helpful reference in the recovery of coal under sand aquifers with intermittent cut-and-fill mining. However, further studies on the field investigation of the stress transformation of the coal pillars to the backfill and the long-term bearing capacity of backfill are needed. Moreover, the creep property of the paste materials and environmental and safety implications of intermittent cut-and-fill mining should also be considered in further studies.

\section{Conclusions}

In this paper, the intermittent cut-and-fill mining method has been investigated. In comparison with longwall and continuous filling mining methods, the intermittent cutand-fill mining has been verified as an effective method to mitigate overburden failure, control surface subsidence and prevent coal mines from groundwater disasters. The case study, which involves the Taiping Coal Mine in the Shandong province of China, demonstrates these benefits of intermittent cut-and-fill mining.

Results of the scale modeling show that mining-induced fractures underwent a cycle of "development-expansioncompaction-closing" along with mining process. And the water-conducting fractured zone takes the shape of a saddle. The space for roof subsidence in backfill mining is smaller than that in longwall excavation, and the backfill provides a support immediately. The interval provided by intermittent cut-and-fill mining can effectively control roof subsidence compared to other mining methods.

The numerical simulation indicates that coal pillars of different sizes during intermittent cut-and-fill mining can maintain stability due to the stress transformation of the coal pillars to the backfill in that the backfill can support the overburden strata. Moreover, the stress distribution in the backfill shows the characteristic of a cycle where the backfilling carried out first bears a larger load than the backfilling carried out later. Moreover, the loads on the coal pillars and backfill gradually increase in tandem with the development of intermittent cut-and-fill, while the stress concentration is the weakest with the smallest factor compared to that induced by longwall excavation and continuous filling.

The results from the numerical simulation and scale model testing show a good agreement and provide a reasonable explanation of the field measurements.

The height of the water-conducting fractured zone and the maximum subsidence due to intermittent cut-and-fill mining show a significant reduction compared to those resultant of longwall excavation and continuous filling as noted from the numerical simulation and scale model testing and verified by field measurements, which indicates that intermittent cut-and-fill mining is an effective way to reduce any further overburden failure and subsidence with coal mining under sand aquifers. Moreover, similar successful cases in China provide practical examples for coal mining under sand aquifers with intermittent cut-and-fill mining. Therefore, overburden failure during coal mining under sand aquifers can be successfully controlled.

Acknowledgements The authors would like to acknowledge the financial support from the 973 Program under Grant No. 2013CB227903, the National Natural Science Foundation of ChinaShenhua Group Jointly Funded Project under Grant No. 51174286, and a Project Funded by the Priority Academic Program Development of Jiangsu Higher Education Institutions. Mr. Wenxue Wang of the North China University of Water Resources and Electric Power and Ph.D. student Binbin Yang of the China University of Mining and Technology are greatly appreciated for their constructive comments for this paper.

Open Access This article is distributed under the terms of the Creative Commons Attribution 4.0 International License (http://crea tivecommons.org/licenses/by/4.0/), which permits unrestricted use, distribution, and reproduction in any medium, provided you give appropriate credit to the original author(s) and the source, provide a link to the Creative Commons license, and indicate if changes were made.

\section{References}

An B, Miao X, Zhang J, Ju F, Zhou N (2016) Overlying strata movement of recovering standing pillars with solid backfilling by physical simulation. Int J Min Sci Technol 26(2):301-307 
Belem T, Benzaazoua M (2008) Design and application of underground mine paste backfill technology. Geotech Geol Eng 26(2):147-174

China State Administration of Coal Mine Safety (2009) Regulations of preventing water hazards for coalmines. China Coal Industry Press, Beijing (in Chinese)

Deng X, Zhang J, Kang T, Han X (2016) Strata behavior in extrathick coal seam mining with upward slicing backfilling technology. Int J Min Sci Technol 26(4):587-592

Djamaluddin I, Mitani Y, Esaki T (2011) Evaluation of ground movement and damage to structures from Chinese coal mining using a new GIS coupling model. Int J Rock Mech Min Sci 48(3):380-393

Fall M, Belem T, Sam S (2007) Experimental characterization of the stress-strain behaviour of cemented paste backfill in compression. J Mater Sci 42(11):3914-3922

Fall M, Benzaazoua M, Saa EG (2008) Mix proportioning of underground cemented tailings backfill. Tunn Undergr Space Technol 23(1):80-90

Fall M, Adrien D, Célestin JC, Pokharel M, Touré M (2009) Saturated hydraulic conductivity of cemented paste backfill. Miner Eng 22(15):1307-1317

Franz D (2008) Similarity theory. Fluid mechanics. Springer, Berlin, pp 193-219

Gao W, Ge M (2016) Stability of a coal pillar for strip mining based on an elastic-plastic analysis. Int J Rock Mech Min Sci 87:23-28

Ghasemi E, Shahriar K (2012) A new coal pillars design method in order to enhance safety of the retreat mining in room and pillar mines. Saf Sci 50(3):579-585

Ghasemi E, Ataei M, Shahriar K, Sereshki F, Jalali SE, Ramazanzadeh A (2012) Assessment of roof fall risk during retreat mining in room and pillar coal mines. Int J Rock Mech Min Sci 54(3):80-89

Ghasemi E, Ataei M, Shahriar K (2014) An intelligent approach to predict pillar sizing in designing room and pillar coal mines. Int $\mathbf{J}$ Rock Mech Min Sci 65(1):86-95

Guo G, Zha J, Wu B, Jia X (2007) Study of "3-step mining" subsidence control in coal mining under buildings. J China Univ Min Technol 17(3):316-320

Itasca (2009) FLAC3D-Fast Lagrangian analysis of continua in 3 dimensions, ver. 4.0. User's manual. Minneaplolis

Iwanec AMS, Carter JP, Hambleton JP (2016) Geomechanics of subsidence above single and multi-seam coal mining. J Rock Mech Geotech Eng 8(3):304-313

Ju M, Li X, Yao Q, Li D, Chong Z, Zhou J (2015) Numerical investigation into effect of rear barrier pillar on stress distribution around a longwall face. J Cent South Univ 22(11):4372-4384

Kostecki T, Spearing AJS (2015) Influence of backfill on coal pillar strength and floor bearing capacity in weak floor conditions in the Illinois Basin. Int J Rock Mech Min Sci 76:55-67

Li L, Aubertin M (2008) An improved analytical solution to estimate the stress state in subvertical backfilled stopes. Can Geotech J 45(45):1487-1496

Li L, Aubertin M, Belem T (2011) Formulation of a three dimensional analytical solution to evaluate stresses in backfilled vertical narrow openings. Can Geotech J 43(3):338-339

Rankine RM, Sivakugan N (2007) Geotechnical properties of cemented paste backfill from Cannington Mine, Australia. Geotech Geol Eng 25(4):383-393

Sui W, Zhang D, Cui Z, Wu Z, Zhao Q (2015a) Environmental implications of mitigating overburden failure and subsidences using paste-like backfill mining: a case study. Int J Min Reclam Environ 29(6):521-543

Sui W, Hang Y, Ma L, Wu Z, Zhou Y, Long G, Wei L et al (2015b) Interactions of overburden failure zones due to multiple-seam mining using longwall excavation. Bull Eng Geol Env 74(3):1019-1035

Tesarik DR, Seymour JB, Yanske TR (2003) Post-failure behavior of two mine pillars confined with backfill. Int J Rock Mech Min Sci 40(2):221-232

Tesarik DR, Seymour JB, Yanske TR (2009) Long-term stability of a backfilled room-and-pillar test section at the Buick Mine, Missouri, USA. Int J Rock Mech Min Sci 46(7):1182-1196

Xu Y, Chang Q, Zhou H, Cao Z, Li X, Chen J (2011) Movement and deformation laws of the overlying strata in paste filling stope. Min Sci Technol 21(6):863-868

Yao Y, Cui Z, Wu R (2012) Development and challenges on mining backfill technology. J Mater Sci Res 1(4):73-78

Yilmaz E, Belem T, Benzaazoua M (2014) Effects of curing and stress conditions on hydromechanical, geotechnical and geochemical properties of cemented paste backfill. Eng Geol 168(2):23-37

Yu W, Wang W (2011) Strata movement induced by coal-pillar under three circumstances exchanged by gangue backfill and quadratic stability law. Chin J Rock Mech Eng 30(1):106-112 (in Chinese)

Zhang Q, Zhang J, Huang Y, Ju F (2012) Backfilling technology and strata behaviors in fully mechanized coal mining working face. Int J Min Sci Technol 22(2):151-157

Zhang J, Li B, Zhou N, Zhang Q (2016) Application of solid backfilling to reduce hard-roof caving and longwall coal face burst potential. Int J Rock Mech Min Sci 88:197-205 